\title{
Ungodly Genders: Deconstructing Ex-Gay Movement Discourses of "Transgenderism" in the US
}

\author{
Christine M. Robinson * and Sue E. Spivey \\ Department of Justice Studies, James Madison University, Harrisonburg, VA 22807, USA; spiveyse@jmu.edu \\ * Correspondence: robin2cm@jmu.edu; Tel.: +1-540-568-5958
}

Received: 8 April 2019; Accepted: 24 May 2019; Published: 17 June 2019

check for updates

\begin{abstract}
This research investigates a neglected topic within both transgender studies and religious studies by analyzing ex-gay movement discourses of "transgenderism" from the 1970s to the present, focusing primarily on the US-American context. The oppression of transgender people in the US and globally is fed and fueled by the religious, scientific, and political discourses of the transnational "ex-gay" movement, which provides the ideological and material foundation of Christian Right politics. Using critical discourse analysis of ex-gay texts, we analyze the implications of these discourses in the individual, interactional, and institutional dimensions of society's gender structure. This movement is one of the most insidious-and overlooked-sources of cisgenderism and transmisogyny today, constructing gender variance as sin, mental illness, and danger-with catastrophic consequences for transgender people, and those along the transfemale/feminine spectrum in particular. Finally, we discuss the public policy implications of these discourses.
\end{abstract}

Keywords: transgender; religion; ex-gay movement; cisgenderism; transmisogyny

\section{Introduction}

If 2014 represented an historic "tipping point" of visibility and progress for transgender Americans (Steinmetz 2014), the vicious, violent backlash that ensued stains the present. Scholarship analyzing the machinations that incite these harms is urgent. This research investigates a neglected topic within both transgender studies and religious studies by deconstructing and analyzing ex-gay movement discourses of "transgenderism", 1 emphasizing the US-American context. Ex-gay discourses appeal to the authority of religion, science, and personal experience to invalidate, condemn, pathologize, scapegoat, dehumanize, criminalize, and rationalize oppressing "people who move away from the gender they were assigned at birth, people who cross over (trans-) the boundaries constructed by their culture to define and contain their gender" (Stryker 2017, p. 1). A long-time Christian Right consort, it is one of the most overlooked purveyors of cisgenderism and transmisogyny today, fueling anti-transgender bigotry and politics throughout the US and globally. Christian Right leaders have unprecedented access and influence in the Trump-Pence administration and at the United Nations; they employ these discourses in every sphere of life.

The transnational Christian ex-gay movement arose in the early 1970s in the US to promote the idea that God can heal people from same-sex attractions. Despite the "ex-gay" moniker, the movement has, from its inception, conceived and condemned homosexuality as a form of gender deviance. Further, ex-gay ministries explicitly targeted "cross-gender" and sexual sins. Since the 1980s, the movement employed "reparative" and other therapeutic discourses which psychologically

1 "Transgenderism" denotes its increasing usage in anti-trans discourses. The term was once widely used neutrally; however, scholars today generally view this term as pejorative. 
invalidate and delegitimize transgender people generally, i.e., cisgenderism (Ansara and Hegarty 2012), and which demonize and scapegoat transfemale/feminine people in particular, i.e., transmisogyny (Serano 2007). Ex-gay organizations regard same-sex desire and gender variance as manifestations of the same root-disobedience to God's divine order for sex, gender, and sexuality. Most also view them as gender identity disorders. The contemporary movement has intensified its attention on transgender people, the focus of this analysis.

The ex-gay movement is a very important part of this backlash. In this article, we analyze ex-gay discourses of "transgenderism" in the individual, interactional, and institutional dimensions of society's gender structure (Risman 2004, 2018). We show it has disseminated cisgenderism and transmisogyny for decades, which animates anti-transgender politics today. Despite the disintegration of the largest ex-gay coalition, Exodus International, the movement has proven resilient, reconstituting ministry networks, expanding its global presence and alliances, and extending its cultural relevance. ${ }^{2}$ Further, it exerts enormous influence in state, national, and transnational politics in partnership with the Christian Right (Robinson and Spivey 2015; Spivey and Robinson 2010). It is experiencing a revival in the Trump-Pence administration. In 2017, President Trump appointed Shannon Royce, a long-time advocate of ex-gay programs to undermine LGBT civil rights, to direct a newly created Center for Faith-Based and Community Partnerships in the Department of Health and Human Services. Diamond (2018) reports that "A small cadre of politically prominent religious activists inside [HHS] have spent months quietly planning how to weaken federal protections for ... transgender care" (p. 11). Royce is one of many for whom ex-gay ideology informs federal and global policy decisions. Finally, we examine the social and policy impacts of ex-gay discourses on transgender people. As Royce once stated: "The ex-gay movement is a very important part of the story" (Shorto 2005, p. 12).

\section{Literature Review}

Scientific and religious rationales and regimes have long been (and remain) implicated in the subjugation of transgender people (Mollenkott 2007; Spade 2003; Winters 2009), and transgender women in particular. Research on cisgenderism helps to identify and explain the mechanisms that normalize and privilege cisgender people and oppress transgender people. Cisgenderism is a prejudicial ideology that operates through authoritative discourses and language to (systemically and on multiple levels) invalidate and delegitimize transgender people (Ansara 2015; Ansara and Hegarty 2012, 2013). Prejudice and discrimination profoundly injure the economic, physical, psychological, and social well-being of transgender people (American Psychological Association 2008).

Scholarship on scientific cisgenderism investigates biological, sexological, sociological, psychological, and other invalidating discourses. Scholars have shown how science is an ideology that reifies the sex/gender/sexuality system (Fausto-Sterling 2012; Laqueur 1992; Lorber 1993) and how scientific cisgenderism is used to pathologize (Ansara and Hegarty 2012; Butler 2006; Lev 2006; McGann et al. 2011; Serano 2007, 2010; Schwend et al. 2018; Winters 2009), dehumanize (Bettcher 2013), and disenfranchise (Greenberg 2006) transgender people. A recent survey (Clark and Jackson 2018) on global attitudes shows that among Western countries, US-Americans are the most likely (32\%) to believe that transgender people are mentally ill. Further, among all 27 countries surveyed, US-Americans are the most likely (36\%) to say that society has "gone too far in allowing people to dress and live as one sex even though they were born in another" and the most likely to believe (32\%) that transgender people "are committing a sin". Finally, research (Cragun and Sumerau 2017) shows that religious and nonreligious US-Americans view transgender people more negatively than other marginalized groups.

2 See Robinson and Spivey (2015, p. 897) for a review of the movement's global reach and impact. "Although conservative Christianity appears to be losing the culture wars over gender and sexuality in Europe and North America, the ex-gay movement continues to flourish there and ... in other regions of the world as well, not only in countries that deny them civil and human rights, but also in progressive countries that provide legal protection for sexual and gender minorities (such as South Africa)". 
Scholarship from theology to religious studies has begun to examine how religion is used to oppress and liberate transgender people. An emerging body of scholarly work, representing theologians, activists, ethicists, and others, critically examines cisgenderism in religious texts, crafts liberation theologies, and articulates the ways that transgender people live their faith and serve religious communities (Beardsley and O'Brien 2016; Dzmura 2010; Lowe 2017; Mollenkott 2007; Rohrer 2009). A recent ethnography (Moon and Tobin 2018) shows how LGBTI conservative Christians transform their ministries to further social justice.

Religious studies scholarship on cisgenderism is urgently needed (Clucas 2015; Sumerau et al. 2015). Research shows that religious affiliation significantly predicts attitudes toward transgender people and policies affecting them, even among US Christians who are liberal on other issues (Sumerau and Cragun 2018). Most Christians believe that birth sex determines whether one is a man or woman, whereas nonreligious people do not (Smith 2017). Studies of discrimination, violence, and crimes against transgender people mostly or entirely ignore the role of religion (Meyer 2015). Scholarship in this area finds that discrimination, violence (Meyer 2015; Rodgers 2018) and dehumanizing/criminalizing rhetoric (Forbes 2017; Mogul et al. 2011; Serano 2007; Stone 2018) disproportionately target transgender women and girls.

Minority stress significantly bears on the physical and mental health of transgender people (Herman 2013; James et al. 2016; Rood et al. 2016). There is very little research in this literature examining either the benefits of religiosity for coping with minority stress or the effects of religious oppression, which increases mental health problems and HIV risk among transgender women (Golub et al. 2010), who fare far worse on every quality of life measure (James et al. 2016). Golub et al. (2010) found that religious organizations that stigmatize transgender people increase mental health problems for those with strong religious beliefs or affiliations with these organizations. Further, transgender individuals attribute anti-trans bias to religious ideology and the media (Rood et al. 2016). Research shows that religiosity can buffer against the effects of minority stress, stigma, and HIV risk among transgender women by reducing depression and improving self-esteem and cognitive functioning (Golub et al. 2010; Hughto et al. 2015).

There is a critical need for scholarship examining how cisgenderism in religious organizations and movements oppresses transgender people, such as Stone's (Stone 2018) analysis of Religious Right campaigns that promote gender panics about transgender children. Stone focused on the political rhetoric that constructs children as immutably gendered, confused, and sexually predatory. In addition, few studies analyze the religious policies and practices of organizations that marginalize transgender people. Scholarship in this vein has deconstructed religious cisgenderism in the official statements and policies of Mennonite conferences (Dueck 2012) and has investigated the experiences of religious oppression among gender variant Mennonites (Dueck-Read 2017). Religious conservatives increasingly invoke religious liberty to justify and codify gender identity discrimination; however, scholars have rarely analyzed religious narratives that animate anti-trans politics (Mathers et al. 2018). Recent research shows that what animates the Christian Right is theology, not politics (Young 2016). Young urges social scientists, in particular, to study the religious aspects of religious studies more deeply.

Deconstructing cisgenderism in ex-gay discourses (religious, scientific, and/or political) has not been a sustained topic of scholarly inquiry. Scholars (Clucas 2017; Robinson and Spivey 2015) observe that ex-gay research exclusively focuses on sexual orientation. Several studies substantiate the movement's sexism; a few analyze the gender ideology of its discourses of homosexuality (for reviews, see Gerber 2015; Robinson and Spivey 2015). Conroy (2010) examined the compatibility between religious mythology and medicalized (not ex-gay) discourses that justify the clinical treatment of transgender children. Several scholars note that ex-gay programs also target transgender people (Butler 2006; Clucas 2017; Herman 2013; Jones 2018; Mallory et al. 2018; Mathers 2017; Robinson and Spivey 2007, 2015; Serano 2016; Tannehill 2018). Clucas (2017) analyzed the rhetorical strategies that two ex-gay organizations use to undermine professional regulation of sexual orientation change efforts and mentions their anti-transgender positions. Mallory et al. $(2018$, p. 2) estimated that nearly 
700,000 US-Americans have been subject to gender identity and/or sexual orientation change efforts "either from a licensed professional or a religious advisor or from both ... including about [half] ... as adolescents". They warn that most states leave youth vulnerable to such attempts.

To date, we are unaware of any research that analyzes, in depth, ex-gay discourses of "transgenderism". While the movement's apparent purpose is to extinguish same-sex desire and neutralize society's acceptance of it, we illustrate that it has simultaneously sought to eradicate gender variance. Our analysis reveals cisgenderism and transmisogyny in the movement's religious, scientific, and political discourses from the 1970s to the present. We also suggest that it exploits greater visibility of transgender people to extend its relevance in the culture wars.

\section{Theoretical Frames: Cisgenderism and Transmisogyny in the Gender Structure}

We employ the concepts cisgenderism and transmisogyny to analyze ex-gay discourses of "transgenderism". Because cisgenderism is "systemic, multi-level and reflected in authoritative discourses" (Ansara and Hegarty 2012, p. 141), it applies to all levels of the gender structure (Risman 2018). We illustrate how cisgenderism in ex-gay texts invalidates transgender people by pathologizing (Ansara and Hegarty 2012) and misgendering (Ansara and Hegarty 2013) them, and in other ways. Transmisogyny (Serano 2016) involves invalidating gender nonconformity and femaleness/femininity in tandem and is useful for identifying forms of cisgenderism that scapegoat, dehumanize, and demonize trans women and others along the transfemale/feminine spectrum because of "the specific direction of their gender transgression" (Serano 2016, p. 89).

Barbara Risman's $(2004,2018)$ gender structure theory explains how people socially construct and employ gender to maintain the sex/gender/sexuality system. This system justifies oppressing gender minorities at all levels of society, from the individual level of gendered selves and identities, to the interactional level of social roles and relationships, to the institutional level where gender is entrenched in organizational policies and practices. We show how ex-gay proponents aim to shape the most intimate aspects of how transgender people think, feel, and act toward themselves, and how they aim to structure gender in the private and public spheres for all.

Applied here, the individual dimension of Risman's framework explains how socialization of religious worldviews and therapeutic lenses shape beliefs, feelings, and judgments about gender, particularly one's own and others' gender identities and expressions. As Risman argues, “... we cannot ignore the power of the gender structure to become internalized within us" (Risman 2018, p. 310). The interactional dimension explains the maintenance of the gender structure through enforcing cisgender norms and social roles. As Risman argues, "[a]ny classification of some human attributes as masculine and some as feminine, and the concomitant gendering of people and social institutions, oppresses all human beings and renders social interaction inherently coercive" (Risman 2018, p. 312). At the institutional level, gender structures public life such that "those who exist outside of a gender binary have few rights-even to exist legally ... Nearly all countries have myriad laws that discriminate against people whose gender does not coincide with the sex they were labeled at birth. In all societies, the material resource allocation and organizational power still rest, predominantly, in the hands of elite men" (p. 39). Gender structure theory allows us to compare our findings with prior research analyzing ex-gay discourses of male and female homosexuality (Robinson and Spivey 2007, 2015). Finally, these frameworks enable us to show how ex-gay discourses contribute to the "cisgendering of reality" (Sumerau et al. 2015). ${ }^{3}$

3 We employ and apply concepts such as cisgenderism, transmisogyny, and the "cisgendering of reality" in our analysis; however, we do not claim to extend any of these conceptually. 


\section{Methodology and Data}

We employed Fairclough's (1992) model of critical discourse analysis (CDA) because it aligns with gender structure theory. Fairclough proposes three analytic objectives of CDA. The first is to identify and deconstruct the meanings of discourses to reveal relations of power embedded in texts (here, ex-gay representations of gender variance). The second is to examine the forms of discursive production, the means of circulation, and the relationships and resources that facilitate, promote, and market the movement's message to explain how discourses reach their intended audiences. The third is to probe the implications and impacts of discourses on sociopolitical arrangements. Here we show how ex-gay discourses aim to invalidate the subjectivity, legitimacy, and autonomy of transgender people in organizational policies and practices.

Data analyzed represent the views of ex-gay leaders and organizations over several decades, as well as affiliated groups (past and present), including a few that are "ex-transgender"-specific. Our large data set includes audio, video, print, and online materials from the 1970s to the present. The organizations most cited are: Exodus International (EXODUS), a Christian ministry network; Exodus Global Alliance (EGA), created in 1995 to coordinate ministries globally; the National Association of Research and Therapy of Homosexuality (NARTH), a professional guild founded in 1992; the Alliance for Therapeutic Choice and Scientific Integrity (ALLIANCE), created in 2014 to rebrand NARTH, and its global division, the International Federation for Therapeutic and Counselling Choice (IFTCC); the Restored Hope Network (RHN), a ministry coalition founded in 2012; Courage International (COURAGE), a Catholic ministry founded in 1980; and Focus on the Family (FOCUS), the largest evangelical Christian parachurch ministry, which had an ex-gay division from 1998-2009. There are a few affiliated ex-trans ministries (and one unaffiliated ministry): Parakaleo (a UK ministry affiliated with EGA, founded by Australian Keith Tiller); CrossOver Ministries and Reality Resources (affiliated with EXODUS and founded by American Jerry Leach ); Help 4 Families (affiliated with RHN and founded by American Denise Shick); New Hope Ministries (a Canadian ministry affiliated with EGA founded by Canadian Danny Blackwell); and Walt Heyer Ministries (founded by American Walt Heyer). We also analyzed texts of allied Christian Right organizations, including Liberty Counsel (LC), the Family Research Council (FRC), Alliance Defending Freedom (ADF), the American College of Pediatricians (ACPeds), and the Pacific Justice Institute (PJI), all of which the Southern Poverty Law Center classifies as "anti-LGBT hate groups" (SPLC 2019).

We procured, transcribed (as needed), coded, and analyzed hundreds of texts. From these data, we identified and prioritized those representing the views of ex-gay/ex-trans organizations, those affiliated with these groups and considered authoritative on "transgenderism" (theologically, scientifically, or legally), and ex-transgender people. We coded texts to (1) identify discourses and interrogate the meanings of "transgenderism" in ex-gay texts; (2) chart the principal means through which the movement produces and delivers discourses to audiences; and (3) assess the social and political import and impact of these discourses for transgender people.

\section{Ungodly Genders}

Ex-gay ideology constructs "transgenderism" as a sin against God's design, a gender disorder, and a catastrophic, extant danger that necessitates intervention. Cisgenderism and transmisogyny permeate ex-gay discourses in every level of society's gender structure. At the individual level, movement authorities interlace theological (Bochanski 2018; Blackwell 2008; Comiskey 2018; Dallas 2008; Foster 2017b; Gagnon 2002; Geiger 2016; Goldberg 2008; Heyer 2018a; Leach 2001; Moberly 1983a; Mohler 2015; Seiler 2016a; Shick 2016a), biological (Nicolosi 2015; Staver 2008; Whitehead 1993, 2000; Whitehead and Whitehead 2016), and psychological (Berger 2013; Dillworth 2016; Dobson 2001; Fitzgibbons 2017a; Foster 2017a; Hale 2012; Haynes 2018; Matheson et al. 2003; Moberly 1983b; Phelan 2015; Pickup 2018; Van den Aardweg 1986; Wong 2013) narratives to deny the veracity and legitimacy of gender variance. They invoke the primacy of God's authority and the derivative weight of science. Transgender identities represent "false images" of God (Gagnon 2007; Leach 2001; Tiller 2015), "gender 
confusion" (Dillworth 2009; Duncan 2016; Kennedy 2008; Rekers 2009; Shick 2016b), and even demonic possession (Robillard 2008). Dutch psychologist Gerard van den Aardweg, an ALLIANCE Board member, describes transgender people as "severely neurotic, sometimes borderline psychotic, and there are cases of demonic influence" (Laurence 2017). Ex-gay experts formulate etiologies in the language of contagion and developmental trauma. "Men and women with transgender struggles" or "unwanted gender identity conflicts" (NTFTE 2017) are warned against the eternal and everyday consequences of embracing a broken image. Accepting one's "God-given sex and gender" is essential for salvation and stability.

At the interactional level, ex-gay discourses urge transgender people to submit to God for deliverance, necessitating pastoral and, often, psychological intercession that requires individuals to identify the origins of their "brokenness" through relationships with Godly mentors and friends of the same sex, renounce transgender identity, and resume cisgender lives. Ex-transgender testimonials witness God's power to heal, validate these directives, and portray transgender life as inherently wretched and untenable. Discourses at this level also exhort cisgender Christians to show compassion to "strugglers", but to avoid colluding in "gender confusion"; to seek help for "GID children"; and to speak God's "truth" about transgenderism. At the institutional level, ex-gay discourses portray "the transgender movement" and its "gender ideology" as profound threats to society. Proponents deem any form of institutional validation of gender variance as heretical, irrational, destructive to religious liberty and a host of "rights", and perilous to women and children. The movement and its allies strive to deny institutional "personhood" and autonomy to transgender people, as bona fide members of the body of Christ, as authorities of their bodies and genders, and as citizens entitled to legal protection. The implications are clear: At all levels of the gender structure, these discourses repudiate and undermine the sanctity and authenticity of gender variance to delegitimize, control, stigmatize, and subjugate transgender people. Transgender women are their most maligned targets.

\subsection{Ex-Gay Transfigurations at the Individual Level: From Religious to Reparative Discourses}

From 1973 (when the first ex-gay ministry was created by Frank Worthen, Kent Philpott, and John Evans) until the mid-1980s, religion was the exclusive method of "healing", and homosexuality the ostensible target. The first ex-gay movement book (Philpott 1975), The Third Sex? Six Homosexuals Tell Their Stories reveals distress about gender variance. Three "former homosexuals" describe non-cisgender childhood identities and expression. "Jim" felt that he was really a girl and wore makeup in high school. "Susan" felt she was a boy as a child. "Bob" liked dolls and wished he could wear his mother's or sister's dresses. From the beginning, ex-gay literature narrated "homosexuality" as symptomatic of a more fundamental gender problem-a "third sex". By 1976, Philpott's book reached others who had created similar ministries. These groups held a conference and created "Exodus". "We're not psychiatrists. The only thing we have to work with is the Gospel" (Philpott, quoted in Carroll 1977, p. 2).

Perry Desmond, who attended that conference, is the first "ex-transsexual" associated with EXODUS (Desmond 1978; Hartzell 2015) and is regarded as "an early pioneer" in the movement (Boone 2012). He evangelized throughout the US in 1976, supporting Anita Bryant's "Save Our Children" campaign (Desmond 1978) and delivering his testimonial (Johnson 1976), which he also gave at an early EXODUS conference (Hartzell 2015). By 1996, 27 of the 81 US Exodus referral ministries and all 4 Exodus ministries in Canada served "transsexuals" and "transvestites" (Exodus International North America 1996). Today, "transgenderism" is prevalent in movement discourse. Frank Worthen, considered "father of ex-gay movement", lamented "the strange and twisted world [where a] doctor can perform a ghoulish operation to make a man in to [sic] a woman and the world applauds his work while the new transsexual is now entitled to government aid ... and a gay man who receives help from a therapist to change ... is ... a traitor ... and the therapist finds himself subject to disbarment and possible criminal charges" (Worthen 2010, p. 1). 
From the 1970s through today, ex-gay religious discourses invoke the Bible to invalidate gender variance and uphold the cisbinary sex/gender/sexuality system ("the gender structure") as God's sacred and inviolable design and the most foundational basis of human identity (Dallas 2008; Moberly 1983a; Payne 1991; Philpott 1975). "Gender is God's unalterable reality", according to "former transsexual" Jerry Leach (2001, p. 34). Leach "struggled with transgender feelings from a young age" and "after years of prayer and counseling, and through Christ's transformative power ... walks in complete freedom from those issues" (p. 11).

Movement advocates invoke scripture to prove God's "created intent", justify prohibitions on "cross-dressing" and genital modification, and stress the consequences of sin (Dallas 2008; Goldberg 2008; Heyer 2018a; Moberly 1983a; Shick 2016b; Tiller 2015). For Leach:

Gender refers to the ... essence of who we are as human beings. It is a mysterious God-given assignment. A most sacred trust and responsibility. The scriptures make it clear ... that God makes us male and female. In the design of our Creator, our gender is not in question. It's written clearly in the basic genetical structure and chromosome xx or xy. It is not to be mistaken for the physiological or anatomical hardware that defines one's sexual identity. In the moment of conception ... gender is a 'done deal'. The ... physiological formations are simply the compliant bodily response to the Divine Assignment (Leach 2001, p. 34).

In ex-gay movement discourses, "transgenderism" is ungodly, sacrilegious, and inhuman (Focus on the Family 2015; Gagnon 2007; Tiller 2015). Help 4 Families (2016) claims it is an "affront to God" and that transgender people are "denying the truth of their God-assigned gender." COURAGE priest Paul Scalia (2016), son of the late Supreme Court justice, describes "gender ideology" as "demonic": "It doesn't mean that those who endorse [it] are demonic or possessed ... rather, that the reasoning and results of that philosophy ... line up with the desires, tactics, and resentments of 'Old Scratch' himself'. God reproves sinners, who will suffer from their brokenness, according to theologian Elizabeth Moberly (1983a). Ex-transsexual Sy Rogers (2009), past EXODUS President and EGA Board member, makes the moral distinction between feelings and identity, attributing his "problem" to his mother's alcoholism and father's abandonment, sexual abuse, a promiscuous culture, his perceptions of and reactions to childhood trauma, and even the "fall" of Adam and Eve. "I may not have had a choice about becoming a victim. I have a choice about staying one". Rogers, an American pastor, founded "Choices" ex-gay ministry in Singapore in 1991. Jerry Leach (2001, p. 35) depicts gender variance as profoundly abject, unbearable to God, imagining Lucifer as the archetypical transwoman:

So many have asked me to site [sic] Biblical examples of God's view toward transsexuality. Though the word Transsexual was coined by a secular authority in the Twentieth Century, the behavior of the transsexual is nothing new. It's [sic] foundational beginnings are recorded in Isaiah 14 and Ezekiel 28-where Lucifer, a created archangel . . . became proud and lifted up because of his own beauty and corrupted his wisdom for the sake of his splendor; profaning himself by the multitude of his own iniquities and enormous guilt. (Ezek 28:17-18) ... It was already quite plain what God's intent for him was to be. But he became puffed up in his own self-bentness, no longer satisfied to keep his God-proscribed place. Ponder it: the devil used to be an angel ... who thought he had a better idea than God for what his real purpose should be in the universe. (See Isaiah 14:12-16).

In this narrative, "transsexuality" — transfemininity, in particular-epitomizes evil: Lucifer-astranswoman, whose pride in "his" feminine beauty overtakes "his" wisdom. Accepting one's place in God's "unalterable" gender order quintessentially defines one's cosmic purpose. To defy this Mandate is not merely sinful; it is demonic, worthy of God's wrath and eternal exile. Descriptions of transfemininity as haughty and narcissistic are common in these texts (Heyer 2013; Leach 2001; Leggiere 2004; Van den Aardweg 1986; Wenman 2017). Perhaps it is worse for a transgender woman to elevate herself above God, or a "male" to relinquish his status. 
The movement's moral framework, and its original target (homosexuality), expanded following the publication of a book by British (Orthodox Church) theologian Elizabeth Moberly (1983a). Moberly primarily sought to reappraise the Christian approach to "homosexuality" based on a "reparative" model she developed from reinterpreting decades-old theories that pathologized homosexuality and transsexualism as stemming from childhood trauma, leading some to "disidentify" from their sex. As Ansara and Hegarty (2012) note, "explaining" gender variance is a form of cisgenderism. This etiology prevails in movement discourse, expert and testimonial (Blackwell 2005; Careless 1997; Ensley 2007; Foster 2017a; Leach 2001; Haynes 2017; Matheson et al. 2003; Nicolosi 1991; Phelan 2015; Rekers 1986; Sargent 1992; Seiler 2016a; Tiller 2015; Wayne 2000; Whitehead 1993; Wong 2013; Worthen 2010). Typical scenarios involve wounds inflicted by parents and/or sexual abuse (Abbott 2009; Dobson 2001; Harbin 2017; Harley 2012; Heyer 2013; Leach 2001; Lloyd 2015; Nicolosi 1991; Payne 1991; Pickering 2016; Pomrening 2010; Rogers 2009; Shick 2016c; Sutton 2015; Takata 2018; Tiller 2005a; Van den Aardweg 1986; Vonholdt 2018). These invalidating narratives are widely disseminated by Christian Right allies who serve ex-gay ministry Boards or offer legal/medical counsel (American College of Pediatricians 2016; Barber 2016; Dacus 2017; Lindevaldsen 2006; Mohler 2015; Navarro 2018; Ohlschlager and Mosgofian 2012; Pacific Justice Institute 2018; Stanley 2015; Stanton 2018; Staver 2009).

According to Moberly, homosexuality and transsexuality embody divergent locations on the wide spectrum of gender disorders caused by a "defensive detachment" from one's sex.

... this process accounts not merely for the whole of the homosexual spectrum, but also for

... the transsexual .... Transsexualism is not ... a rationalization of homosexuality. It marks the extreme end of the homosexual spectrum, but precisely because the same-sex deficit is so marked, it is proper to speak of actual gender dislocation. Most homosexuals do not wish for gender reassignment, because ... the deficit is not so marked. There [is] ... overlap ... some homosexuals may suffer from a marked degree of same-sex deficit, whether or not this ... expresses itself in a demand for gender reassignment ... not all homosexuals are transsexuals ... . (T)ranssexualism in both sexes has the same psychodynamic structure as homosexuality. The difference is essentially one of degree, not of kind. Transsexualism is the most marked degree (Moberly 1983a, pp. 12-13).

For Moberly (1986), transsexuality is not a "true" cross-gender identity, but rather the "radical absence" and most extreme form of "disidentificaton". People with same-sex desires may or may not exhibit cross-gender behavior or be transsexual. Same-sex desire, in itself, is serious, but less so than transsexuality. Transsexuals may or may not experience same-sex desire. Transsexuality is part of the "homosexual continuum" because of the severity of detachment, not sexual desire.

Moberly's primary purpose is theological-to propose a "new Christian ethic". She accomplishes two key, interrelated goals. First, she offers a theology that calls for Christian compassion and ministry to the afflicted, while upholding prohibitions on sexual/gender transgressions. Second, she presents an etiology and a psychoreligious therapy for a continuum of disorders ranging from those that indicate lesser degrees of detachment, such as heterosocial behavior; to greater degrees, such as same-sex attraction; to ever more serious detachment, such as "cross-dressing"; to the most severe form, "transsexualism". Moberly's etiology poses disturbing doctrinal implications. She contends that Christian condemnation misunderstands the nature of homosexuality. Moberly, like those she cites, presents gender "deviance" as developmental disorders that arrest psychological maturity, thus infantilizing everyone on the "homosexual continuum", especially transsexuals. What defines "homosexuality" is not sexual:

[It] ... is not intrinsically sexual. The issue is ... growth and development to psychological maturity ... the true point of comparison for homosexuality is not sexual pair-bonding, but the parent-child relationship ... the end result of this process of growth is heterosexuality, understood as the capacity for relating to people as a psychologically complete member of one's own sex (Moberly 1983a, p. 21). 
For Moberly, transsexualism is "radically incomplete psychological growth, stemming from ... psychological wounds of very early childhood. What we are speaking of is not 'craziness,' but the suffering of little children" (pp. 14-15). This ontology lays bare the theological implications of sexual behavior for everyone on the homosexual spectrum, especially transsexuals:

Sexual sin is contrary to God's intention, but homosexuality, although often an occasion for sexual sin, is essentially a state of incomplete development. It is the incompletion that is contrary to God's will here. Homosexual acts are prohibited, not because they repudiate the man-woman relationship, but because sexual expression is not appropriate to pre-adult relationships (Moberly 1983a, p. 57).

The ex-gay movement embraced Moberly's ideas, which profoundly complemented and widened its moral framing and healing approaches to include both religion and psychology. Significantly, in redefining same-sex attraction as one manifestation of "defensive detachment" along a "homosexual" spectrum that includes transsexuality at the "extreme end" (p. 14), Moberly cisgendered ex-gay theology by shifting the movement's gaze from the sin of same-sex sexual behavior to a range of infantilizing gender identity problems that have the same root and solution. She also severely transfigured the meaning of sexual sin.

Moberly significantly influenced the "medicalization" of ex-gay discourses. However, religion remains authoritative and essential for her and others who aim to heal "gender confusion" (Blackwell 2008; Dillworth 2016; Fitzgibbons 2005; Fitzgibbons and Nicolosi 2001; Fitzgibbons et al. 2009; Goldberg 2008; Leach 2001; Matheson et al. 2003; Payne 1991; Phelan 2015; Robertson 2004; Rosik 2001; Shick 2015; Tiller 2005b; Van den Aardweg 2011; Vonholdt 1996; Wong 2013). “It is God who heals, and so our dependency on God is all-important" (Moberly 1983a, p. 43). Even so, the movement advanced therapeutic approaches ("reparative" and other) to complement its ministry. Though the ex-gay movement did not invent scientific cisgenderism, the reparative framework delivered it to a wider audience. The movement's turn to science enhanced its credibility at a crucial historical moment, the onset of the AIDS crisis, which guaranteed more (and more fearfully motivated) clients. This framework also expanded the prospects for whom they could serve (transgender people) and supplied the ideological and evidentiary keystone for today's most ferocious culture war.

At the individual level, ex-gay discourses appeal to God, science, and personal experience to invalidate the authenticity of gender variance, constructing it as sin, a denial of biological reality, and an infantilizing gender disorder. Reparative etiology separates the moral status of one's condition from culpability for one's conduct. It offers compassion and the promise of healing (Moberly 1983a), yet condemnation for rejecting God's Assignment (Leach 2001; Rogers 2005, 2009; Tiller 2015) to compel believers to submit to its regimen. Ex-transgender testimonials bear witness to the "roots" and "fruits" of iniquity and confusion, and the deliverance of God's grace. Those who choose "change" are victims (real or perceived) and redeemable; those who resist are narcissistic, delusional, and incorrigible (especially transgender women).

Deconstructing ex-gay discourses at the individual level reveals an ideology that uses religion and science to coerce transgender people to deny the authenticity and integrity of their own genders, bodies, minds, and souls. They shape how believers interpret what gender variance "is" and what it "does". At the interactional level, they provide instructions for how individuals can prevail over their brokenness, how parents can prevent "gender confusion" in children, and what believers should "do" in their interactions with transgender people: Invalidate them.

\subsection{The Interactional Level: Compulsory Cisgendering and the Incitement to Invalidate}

At the interactional level, ex-gay discourses of "transgenderism" reproduce the gender structure by defining and enforcing Godly (cisgender) roles for all of society's members and by enjoining others to discourage gender variance and invalidate transgender people. The narratives at this level primarily target three groups: Adults with "gender confusion"; parents, as a preventative or remedy 
for "gender-disturbed children" (Rekers 1986, p. 28), which "experts" warn is urgent (Adams 2005; Dillworth 2002; Fitzgibbons 2015; Moberly 1983a; Nicolosi 1991; Shick 2016b); and fellow believers, to extend God's "grace" and speak "truth" to others. The movement's authorities compel strugglers to submit to their restorative prescriptions and exhort parents to prevent "confusion" in children by modeling and enforcing cisgender roles. Ex-transgender testimonials reinforce these interventions. In this section, we outline and analyze the reparative approach for restoring cisgender identity in adults. In addition, we analyze themes and discuss the implications of testimonials of deliverance. Finally, we illustrate how ex-gay proponents incite others to invalidate gender variance and transgender people.

The reparative processes that Moberly and others (Leach 2001; Nicolosi 1991; Phelan 2015; Van den Aardweg 1986) advocate for healing gender identity are the same as for sexual orientation. They are detailed elsewhere (see Robinson and Spivey 2007, 2015). ${ }^{4}$ However, because Moberly considers "gender dislocation" as more serious than same-sex desire, and "transsexualism" the most acute condition on the homosexual continuum, she points out that "a lengthy process of intensive therapy is likely to be indicated" (Moberly 1983b, p. 76). "Healing" occurs through a trinity of relationships: First, with God (as Father), second, with a Christian mentor/counselor of the same "anatomic sex" (Moberly 1983a) who functions as a pseudoparent, and third, with "healthy" same-sex peers who model Godly masculinity or femininity. "Relationships are the normal medium for psychological growth within the purposes of God ... [relationships are] ... God-given channels for healing" (pp. 46-47). Moberly's prescription purports to undo "the defensive detachment from the same sex" and make up for "the missing identificatory growth" (pp. 30-31) in order for one's (cis)gender identity to emerge. Through one's relationship with God, the individual relinquishes his or her autonomy, is penitent and prayerful, and seeks God's forgiveness and assistance in healing. Through working with a Christian counselor, the person identifies the source(s) of childhood wounds and engages in a process of forgiving the perpetrator(s). Finally, through developing "healthy" same-sex peer relationships, the struggler learns to relate to members of the same sex, and to live as a Godly man or woman. For Moberly, "At the heart of it all, Christ himself is the healer" (Moberly 1983a, p. 47).

The ex-gay movement is, above all, a religious (ecumenical) one. Catholic psychologist Joseph Nicolosi co-founded NARTH as a secular, scientific guild for reparative therapists. Clucas (2017, p. 10) reveals this front as a "smokescreen" for conservative religious beliefs. Nicolosi presents himself as an expert on "transgenderism" in a film featuring fifteen "ex-transgender" people (Foster 2017a) and on the Dr. Phil Show, claiming "gender-disturbed boys" usually have "over-involved mothers" (Nicolosi 2009). For Nicolosi, Christ is the "perfect cure":

For John .... Candi represented not only his gender-identity confusion, but a fantasy alternative to the difficult challenge of becoming a man. When he gave into the identity of Candi, he relinquished his manhood. Religion's power to heal ... comes from its ability to ground one's authentic identity ... in a source outside the self ... the transcendent reality of Christ ... the living Christ dwelling within us is ... the perfect cure for narcissism and self-deception .... Christ and Candi could not coexist within the same soul. When Christ came in, Candi went out. It had to be, simple as that ... . The principles of reparative therapy are quite compatible with Christian theology .... The vocabulary is different, but they explain the same phenomenon: healing" (Nicolosi quoted in Paulk 1998, pp. xii-xiii).

Robert Gagnon (2015b), a Presbyterian theologian on the RHN Board, agrees, defending the congruence of reparative therapy and Christianity. Former NARTH officer Arthur Goldberg (2008), founder of a Jewish ministry closed by consumer fraud litigation, argues it is compatible with Judaism. RHN and FOCUS Board member Albert Mohler, President of the Southern Baptist Theological Seminary,

4 Because the restoration and prevention processes are similar to and detailed in depth elsewhere, the interactional section is shorter than the individual and institutional sections. 
supports reparative therapy but warns: "We cannot ... allow ourselves to mistake a medical definition for a moral and spiritual reality (Mohler 2011, p. 84). "Therapy will never save us ... . only Christ can do that" (p. 167). In the movement, there are several approaches in addition to "reparative" therapy (Cox 2009). Some focus on changing gender/sexual orientation; others focus on behavior. Some are exclusively pastoral; others use clinical techniques. These include 12-step and addiction models (Blackwell 2005), "gender-affirmative" therapy (Byrd and Olsen 2002; Goldberg 2007), "gender wholeness" therapy (Matheson 2013), "healing prayer" (Payne 1991), "reintegrative therapy" (Long 2018), trademarked by Nicolosi's son, Joseph Nicolosi, Jr., and others. NARTH psychologist George Rekers (also a Baptist minister and a founder of FOCUS and FRC) published an article that NARTH's official journal reprinted, referencing a "study" of a doctor who diagnosed a transsexual woman as possessed by evil spirits and cured her by exorcism. Rekers (1986, p. 29) cites the exorcism study as preliminary evidence of the "positive therapeutic effects of religious conversion for curing transsexualism" and urges further research. Regardless of the method, universally endorsed among them are two truths: God is the source of healing, and "transgenderism" is ungodly.

Ex-transgender testimonials figure prominently in validating these religious and, in many cases, therapeutic techniques (Foster 2017a; Rogers 2009; Pomrening 2010; Seiler 2016b). They universally witness pursuing God's will for their lives. Many also attest to the reparative processes of healing from the wounds that led to their condition, which occur through relationships with God and His human vessels_-"Jesus with skin on"-including counselors who serve as surrogate parents and peers who provide "healthy" same-sex friendships. Some proclaim complete "freedom". For most, wholeness is neither the absence of "struggle" nor the purity of one's gender expression, but rather measured by "faith" and "works" - devotion and submission to God's authority. As Kathy Grace Duncan explains (Foster 2017a), freedom is being "who God created me to be ... . It's not about being feminine, it's about being holy ... . If you are obedient ... . About my femininity ... I'm not done, by any means, but I am free".

Even so, testimonials sensationalize gender transformation to contrast the brokenness of their former lives with the holiness they have found as new creations. They depict "the transgender lifestyle" (Harley 2012) as inherently tragic, resulting in loneliness (Wenman 2017); alcoholism or drug use (Foster 2017a; Heyer 2013; Showalter 2017); prostitution (White 1987); self-harm, such as attempted suicide (Comiskey 2014; Gagnon 2007; Heyer 2013) or self-castration (Leach 2001); and severe depression (Heyer 2013; Tiller 2005b). Experts and testimonies narrate "transgenderism" as "deception" (Tiller 2015); "idolatry", envy, or jealousy (Blackwell 2008; Evangelical Alliance and Parakaleo Ministry 2006; Geiger 2017; Leach 2001; Phelan 2015; Van den Aardweg 1986); lust (Foster 1996; Leach 2001); and obsession, addiction or "bondage" (Blackwell 2005; Dallas 2008; Hall 2015 ; Moberly 1983a; Tiller 2015; Van den Aardweg 2015; Whitehead and Whitehead 2016). Most testimonies are by men (ex-transgender women), who often portray their former fixation on appearance in ways that denigrate femininity as superficial.

Finally, ex-gay discourses at this level target fellow believers, exhorting them to "reach out" to transgender people with compassion ("God's grace") and "truth" (Bochanski 2018; Geiger 2017; Shick 2015; Wright and Moody 2016). These narratives instruct believers to invalidate transgender people in their interactions to discourage gender variance. The documentary, TranZformed: Finding Peace with Your God-given Gender (Foster 2017a), features Joseph Nicolosi as a psychologist and Christian demonstrating (and obliging others to do) this:

How do I, as a Christian, respond to this disturbed person? Certainly not condemning, not to make them feel bad .... Also, I have a commitment to not collude with your delusion. I'm not going to call you Mary, okay? Your name is Tony. It was Tony a month ago, and you're still Tony, okay? I may spare you the stress of me insisting 'You are Tony'. I'll say 'Hi, how are you?' But I have to make a decision. And each individual has to make a decision. If I am grounded in the natural law, which is compatible with Christianity, and Judaism ... then 
how do I respond to this person with compassion, but not to collude with their delusion?

And that's a decision, a boundary, that has to be found with each individual.

Some (Blackwell 2008; Roberts 2016) encourage believers to build relationships with transgender people and to use their chosen names, at least until they have cultivated enough trust to then speak "truth" to them. At the institutional level, movement discourses incite believers to "respond" as citizens to the dangers that "transgender ideology" and people pose to society.

\subsection{Institutional Erasures: The Social Death of Transgender People}

The social position of transgender people in the US and globally is fed and fueled by the religious, scientific, and political discourses of the transnational ex-gay movement, which provides the ideological and material foundation of Christian Right politics at the institutional level. Movement advocates have unprecedented influence to shape public policy affecting transgender people, as advisors and appointees in the Trump-Pence administration and at the United Nations. Cisgenderism and transmisogyny in these discourses at the individual and interactional levels have profound applications to and implications for the very personhood of transgender citizens at the institutional level of the gender structure. In this section, we analyze the movement's political discourses, sketch its intimate collaboration with the Christian Right, and discuss the public policy implications for transgender people.

Today's movement articulates "transgender ideology" as a social contagion - as both engineer and outcome of sin. It infects society's institutions, corrupting a nation progressively unmoored from biblical values (Dallas 2017; Exodus Global Alliance 2018; Fitzgibbons 2017b; Nolland et al. 2018; Reisman and McAlister 2016; Rogers 2009; Shick 2016b). Therapist Marc Dillworth (2009), affiliated with NARTH and Hope for Wholeness, ascribes the declining stigma of gender variance to "a breakdown in our Judeo-Christian worldview .... This is happening nationwide and ... in the mental health field, because we no longer live in a Christian society". Walt Heyer (2013) indicts all who take part in this "grand delusion", including transgender studies, but particularly doctors who provide transition care, like "Dr. [John] Money, reckless narcissist", as conspiring with societal degeneracy: "These damn doctors ... think ... they are God ... chang[ing] a child's God-given sex". Denise Shick (2016b) offers a parable of gender variance as alien contamination of families, abetted by media and progressives:

Jenner's transition [has] given ... [society] permission ... to embrace transgenderism [and] $\ldots$ actively promote it ... progressives are ... jumping onto the transgender shuttle pod ... parents are ... starting to spot the metaphorical mothership ... It's in their homes ... implanted alien DNA in their children's bloodstream.

Movement leaders denounce "revisionist theologies" that sanctify gender variance as heretical (and sometimes Gnostic) threats to Church doctrine, and as ruinous for souls and human civilization itself (Brown 2016; Dallas 2008; Focus on the Family 2015; Leach 2001; Mohler 2015).

Ex-gay political discourses catastrophize recognition of gender variance in explicitly patriarchal terms: A "crisis in masculinity" (Payne 1999) polluting every institution, resulting in chaos throughout the social body. It is a particular threat to an already "weakened" "natural family", the basis for civilization (Focus on the Family 2015; Mohler 2005). Transmisogyny and cisgenderism permeate claims of harm to families (Hall 2013; Heyer 2013; Leach 2001; Shick 2011; Tiller 2005b). Family testimonials, such as (Australian) Gae Hall, whose "ex-husband" is a transgender woman, and Denise Shick, the daughter of a transgender woman, claim to speak for "families ... impacted by cross-dressing or gender identity disorders, (who) find their world filled with spiritual and personal confusion, pain and grief ... (L)osing a loved one to a gender disorder is similar to experiencing the loss of a family member to death" (Shick 2015, p. xiii). Cross-dressing is "weakness rather than faith" and "elevates one's own desires at the expense of needs of others" (Hall 2015, p. 144). These accounts depict such "men" as self-obsessed, depraved persons who forsake their manhood for "the flesh", which robs families of 
fathers, husbands, providers, and protectors. Shick details, for a US Supreme Court amicus brief, how her father wore her clothes, left her mother, financially devastated their family, and repeatedly sexually abused her. The brief includes "a photograph of Denise Shick's father as 'Becky'" (Boyle 2015, p. v), and attributes all of this to a "transgender household". Testimonies of family harm in policy contexts aim to deny legal recognition, marriage, civil rights, and medicine to transgender people (Boyle 2015; Heyer 2018b; Evangelical Alliance Policy Commission 2000; Lindevaldsen 2006).

Leaders view Christians as victims under siege and urge citizen action "defending the family and society" (Burack 2008; Robinson and Spivey 2007). The "transgender revolution, even more than ... gay liberation, undermines the most basic structures of society" (Mohler 2015, p. 69). Richard Fitzgibbons, ALLIANCE officer and Vatican consultant, insists that society treat, not accommodate, gender disorders, quoting Pope Benedict's injunction that the Church "has a responsibility for the created order to make this responsibility prevail, even in public" (Fitzgibbons 2015). RHN's David Foster (2017b) depicts the gravity and scale of the threat:

There is a war of the worlds going on in the shadows of our everyday awareness-an unseen battle between the Creator God (YHWH) with His army of heavenly beings and Satan with his fallen angels and demonic hosts. Nowhere is this battle more pronounced today than in the rise of the transgender movement. It is the front lines in Satan's scheme to deface and destroy the image of God that is stamped onto our personhood, sexuality, marriages, children, and families.

Foster names several institutional "forces of confusion" that conspire with Satan, the "wealthy and powerful LGBT movement", the "wealthy and powerful professional guilds", the "media ... government, education, the AMA, public schools, colleges ... the false church and a deceived public". In response, the movement has developed, over decades, a coalition of professional networks (religious, legal, educational, and scientific) to rally against this Goliath.

The relationship between ex-gay and Christian Right groups is mutually beneficial. Ex-gay discourses provide the ideological and material basis of Christian Right litigation, legislation, and policy advocacy. In turn, the Christian Right supplies publicity, referrals, and legal counsel. These discursive invalidations enable both to present their truth claims as evidence-based and objective, and to establish standing in policy contexts. They deny subjectivity, autonomy, and civil and human rights to transgender people while claiming the moral high ground by offering compassion and hope-portraying themselves as arbiters of Truth, protectors of women and children, and guardians of liberty and civilization itself.

Ex-gay and Christian Right professionals are engaged in anti-transgender advocacy at local, state, federal, and international levels. Christian legal firms cultivate partnerships with ex-gay (Barber 2016; Dacus 2017; Liberty Counsel 2016, 2018; Lopez et al. 2018; Williams 2018) and allied health associations (Alliance Defending Freedom and North Star Law and Policy Center 2017; Clinton and Ohlschlager 2010; Heath 2018; Lindevaldsen 2006; Stanley 2015; Staver 2007, 2009) for their mutual benefit. In 2002, NARTH submitted an amicus brief in a lawsuit filed by LC where the Kansas Supreme Court ruled that a "transsexual" is not a woman, voiding her marriage and inheritance. LC attorney and Liberty University law professor Rena Lindevaldsen explained at a NARTH conference (Lindevaldsen 2006) how LC's anti-transgender litigation relies on their collaboration:

I would like NARTH members to work more closely with the legal community ... we need you to fight the battle in court ... submit expert declarations ... publish sound research ... critically analyze others' research ... locate, and understand the significance of ... medical research. Now more than ever, courts rely heavily on journal articles to aid them in rendering a decision. We will not be able to continue to protect children and families without your help ... . if Lambda Legal and others ... sue you for engaging in reparative therapy, we will be there to defend you-armed with ... research on SSA and GID ... . If we hope ... to protect children and families ... and the right of doctors to engage in reparative therapy 
and to treat GID as a mental disorder ... then the legal and medical communities must join together ... toward this common goal (p. 8) .... Working together, we can ... protect the rights of patients to receive, and your right to offer, reparative therapy. [We] need to ... jointly demand respect for an equality and diversity of viewpoints on the origins, causes and treatments for SSA and GID (p. 30).

In the US and abroad, this legal-medical alliance uses several discursive frames to undermine institutional personhood for transgender people; we briefly discuss science, religious liberty, and harm. Clucas (2017) analyzed the secular and scientific framing used by NARTH and Core Issues Trust (a UK ex-gay ministry) to resist against professional regulation of sexual orientation change efforts (referred to as SOCE in mainstream psychology and in some ex-gay literature $)^{5}$, which revealed these rhetorical tactics as a "... a smokescreen for conservative Christian values" (p. 447). Clucas provides a nuanced analysis of ex-gay framing strategies related to sexual orientation. Due to limited space, we briefly show how the ex-gay movement and their allies employ cisgenderism through scientific, religious liberty, and harm frames to oppress transgender people in every sphere of public life. They appear in legislative, judicial, and professional regulatory hearings; in court briefs, conference presentations, and publications; and in various media to prompt citizen action, in the United States and around the world.

The movement uses scientific framing to prevent government recognition of transgender people (American College of Pediatricians 2018). They aim to establish gender variance as a treatable mental disorder to undermine civil rights, to deny bathroom access (McHugh et al. 2017), to discredit and deny transition-related medicine (American College of Pediatricians 2018), and to abolish and prevent professional regulation and laws banning "change" therapy. Some proponents analogize gender variance to limb amputation disorders (American College of Pediatricians 2016; Brown 2015; Hruz 2018; Lorence 2016). For RHN co-founder Andrew Comiskey (2018), "Claiming that this is a civil rights matter and encouraging surgical intervention is in reality to collaborate with and promote a mental disorder". ACPeds President and ALLIANCE officer Michelle Cretella declared: "The science is clear: no one is born transgender ... No one has a civil right to a developmental disorder" (Berry 2015). Recently, Cretella, ex-transgender activist Walt Heyer, and FRC President Tony Perkins lobbied Congress to oppose Equality Act legislation the day after it was introduced, which would add gender identity and sexual orientation to federal civil rights laws (Gogarty 2019). Tim Clinton, president of the American Association of Christian Counselors (AACC), serves on Trump's evangelical board. Several counseling guilds, representing thousands of licensed professionals, endorse "therapy" to change gender identity, including AACC (Haynes 2017). If, they reason, gender variance is a disorder or malleable ("treatable"), laws banning "change" therapies are not evidence-based and transgender people are not entitled to Constitutional recognition. The US judiciary uses three criteria to confer protected class status, one of which is a group's "immutability" (Nussbaum 2010). Finally, advocates (American College of Pediatricians 2018; O'Leary and Sprigg 2015; Staver 2008) argue that the law must establish legal sex based on birth physiology as the only "objective" criterion. According to Staver (2016), "the federal law never intended to allow people to change their general [sic] by fantasizing that they are something other than reality". These discourses function as an "epistemological regime" in which the experiences and self-knowledge of transgender people "becomes delegitimated as merely subjective" (Stryker 2008, p. 154). They show, profoundly, how "the psychological is political" (Dworkin and Yi 2003, p. 269).

The movement advocates in Germany (Vonholdt 2018), Malta (Davidson 2019), the UK (Davidson et al. 2018; Evangelical Alliance Policy Commission 2000; Wright et al. 2016), and the UN (Navarro 2018). Alliance Defending Freedom International's (2015) brief to the European Court of Human Rights defended the right of nations to require sterilization before issuing identity documents,

5 In the US, state laws that ban licensed practitioners from "sexual orientation change efforts" on minors also prohibit attempts to change gender identity and/or expression. For clarity, we use "SOGIE change efforts" to denote attempts to change sexual orientation, gender identity, and/or gender expression. 
noting "transgenderism" is a mental disorder. NARTH psychiatrist Joseph Berger (2013) addressed a parliamentary body revising the Canadian Human Rights Act to prohibit gender discrimination, urging them "not to grant special rights to people who are unhappy with the sex they were born into, or to people who wish to dress in the clothes of the opposite sex". He claimed, "Scientifically, there is no such thing" and that "the medical treatment of delusions or psychosis is not surgery". Berger once advocated in an article on the NARTH website: "letting children who wish to go to school in clothes of the opposite sex-but not counseling other children to not tease them or hurt their feelings. On the contrary, don't interfere, and let the other children ridicule the child who has lost that clear boundary ... Maybe in this way, the child will re-establish that necessary boundary" (Burroway 2006). NARTH removed the article and apologized in response to criticism.

The implications are clear. If medicine and law deny the legitimacy of gender variance, transgender people do not exist and have no claims to rights or autonomy over decisions affecting their bodies, minds, or legal status. Identity documents are vital for self-sufficiency, from driver's licenses, to bank accounts, to job applications, to medical care. Accomplishing this would render transgender people civically dead, "ineligible for personhood" (Cacho 2012), sanctioning their social death, leaving them more vulnerable to discrimination, poverty, violence, and criminalization (Forbes 2017). "[M]edicalization has implications for social control, power, knowledge, authority, and personal liberty" (McGann and Conrad 2007, p. 1110).

The movement also invalidates transgender people at the institutional level by invoking religion directly, using "religious liberty" and "religious diversity" as frames to level rights-based arguments (and indirectly, appealing to "conscience", "self-determination", and other ethical professional principles). Recent efforts include "defending" parents' and licensed professionals' religious "right" to procure or practice SOGIE change on minors (Baltimore Sun 2019; Phelan and Doyle 2014; Pruden 2009; NTFTE 2017; Staver 2007) and advocating for clients' religious right to choose therapy (California Legislative Council 2012; Clinton and Ohlschlager 2010; Clinton and Scalise 2016; Dallas 2016; Harley 2012; Haynes 2017; Pacific Justice Institute 2018; Staver 2009; Welch et al. 2013). ALLIANCE officer Philip Sutton (2015, p. 356), notes that self-determination " ... does not equally apply to gender reassignment and other related procedures which have documented harm..." Religious liberty is directly invoked to deny bathroom access (Dallas 2017; Heyer 2018b; Staver 2016); prevent schools from teaching about or tolerating gender variance (Dallas 2017; Davidson et al. 2018; Liberty Counsel 2015; Wright et al. 2016); prohibit transition care (Congressional Record 2016; Diamond 2016; Fitzgibbons 2011; Lindevaldsen 2013); and discriminate in religiously-affiliated institutions, including churches and schools (Sharp 2016; Williams 2018).

These efforts are also underway abroad. In 2018, FRC President Tony Perkins was appointed by Senator Mitch McConnell to the US Commission on International Religious Freedom, which advocates for freedom of religion or belief abroad and makes policy recommendations to the President, Secretary of State, and Congress. ALLIANCE's international division, IFTCC, includes two barristers on its board: Paul Diamond, who specializes in religious liberty and free speech in England and Europe, and Andrea Williams, who specializes in "Christian" liberties and practices in the British judicial system. Diamond recently represented a UK psychotherapist who sued a university because its research ethics board denied his client's proposal to study why some transgender people detransition. Williams (2018), founder of the UK Christian Legal Center, represents Nigel and Sally Rowe, who removed their children from a Church of England primary school, which they are suing for allowing gender variant students. Sally Rowe told BBC Radio (2017): “We believe it is wrong to encourage very young children to embrace transgenderism ... Gender dysphoria is something we as Christians need to address with love and compassion, but not in the sphere of a primary school environment".

Finally, cisgenderism and transmisogyny are politically useful in the Christian conservative trope of "protecting women and children" from harm, which they exploit to subvert feminism, gay rights, and the civil and human rights of transgender people. From Phylis Schlafly's warning that the ERA would undercut a husband's ability to protect his wife, to Anita Bryant's "Save Our Children" campaign 
depicting gays as sexual predators (also spread by ex-gay leaders), contemporary discourses incite gender panic (Westbrook and Schilt 2014) and scapegoat transgender women. Advocates (Barber 2016; Cretella 2017; Heyer 2018b; Van den Aardweg 2015) allege that permitting gender variance in children is "child abuse". Quentin van Meter (affiliated with ACPeds and IFTCC) speaks worldwide (Van Meter 2018), calling transgender medicine "fraud" and "the growth of transgenderism" "perverse". Influential leader James Dobson (2016), (FOCUS and FRC co-founder, RHN board member, and Trump Evangelical Board advisor) exhorts men to enact "manhood" to "defend" "their" wives and daughters from "perverts":

If you are a married man with any gumption, surely you will defend your wife's privacy and security... Would you remain passive if a strange-looking man, dressed like a woman, has been peering over toilet cubicles to watch your wife ... ? What should be done to the pervert who was watching ... women and girls in their stalls? If you are a dad I pray you will protect your little girls from men who walk in unannounced, unzip their pants and urinate in front of them ... . 100 years ago, someone might have been shot. Where is today's manhood? God help us!

Dobson is more alarmed by what he imagines—deceptive "men" preying on women and children-than actual harms perpetrated daily by cisgender men. As Nussbaum (2010) has shown, projective harm is often a more powerful weapon than actual harm in formulating the law. Dobson endorsed candidate Trump, who bragged in 2005 about "getting away with" walking in on naked beauty pageant contestants (some as teenagers). Dobson also endorsed Senate candidate Roy Moore, accused of sexually assaulting teenage girls. FOCUS President Jim Daly blogged (Daly 2012): “Why This School is OK with a Man Exposing Himself to Young Girls". Jerry Boykin, Vice President of FRC, said at a LC conference (SPLC 2016):

Where are the Christians of America today?... They should be flocking to the city council to say 'No, you're not going to let a man go in my daughter's bathroom, just because he feels like a man today ... Where are the Christians that are standing up to [this] kind of evil? ... I'll tell you what. The first man that walks in my daughter's bathroom, he ain't gonna have to worry about a surgery.

Boykin also endorsed candidate Trump. FRC's legal arm, ADF, is the source of most of the state-level anti-trans legislation in the US ( $\mathrm{O}^{\prime}$ Hara 2017). Projecting imaginary predation and encouraging violence against transgender women is troublesome enough. In 2013, PJI (which submitted a legal brief opposing California's 2014 law requiring public schools to allow students to use the bathroom according to their gender identity) falsely claimed that a transgender girl was harassing other girls in the restroom (Ford 2013). These narratives "culturally criminalize" (Mogul et al. 2011) transgender girls and women. In 2009, Circuit Judge Neil Gorsuch dismissed a transgender woman's claim that she was denied access to the women's restroom at work and lost her job. Gorsuch ruled that the employer's "safety concerns" were legitimate. These narratives also conceal the actual harm these groups encourage and perpetrate directly. PJI attorney Brad Dacus spoke at the 2017 RHN conference and said he was encouraged about the future of the Supreme Court "for ministries like yours" after he heard Justice Kennedy would retire next summer. He detailed legal advice he gave to two families with transgender children, and a private Christian school. He begins with a call he received from a pastor in San Diego:

He called me because they were concerned about a visit from a social worker involving a 13-year-old girl who said she is going to be a boy. The pastor said 'Someone from church said we should call you'. I said 'Thank you, Lord. Well, what are you going to say?' 'We're going to say we're Christians. We believe what the Bible says. We think this is a sin ... we're going to get counseling... ' And I said 'Okay. You just lost your child.... This is what you are going to say: You are very appreciative of that social worker's efforts to bring tolerance and 
sensitivity to families like theirs and that you have $100 \%$ unconditional love for your child no matter [what]...' And there's some truth in here, okay? People will say 'That's not really Christian'. And I say, well, what about Moses' mom? They knocked on her door. Did she say, 'Oh yeah, you caught me. It's in the basket ... down the river to the right'. No. She didn't do that. She said 'There's no baby here... Why? Because you want to prevent the greater evil, having a child taken. So we want to be wise and discerning. We gave that counsel. They have their daughter. We had another case up in Sacramento. A man calls me and says, 'My daughter is coming out, she's 15. Counselor's coming tomorrow. What should I say?' Exact same problem. I gave the counsel and they went away. Then I said, 'You need to have that child ... in a private Christian school, start some counseling'. And he said, 'What if the ... school says they won't do anything? What if they won't let her in?' I said, 'What school are you thinking about?' and he said such and such .... I said 'You may be surprised'. What he wasn't aware of is that, by God's sovereign grace, in three days I was scheduled to address that ... school and the Church's board ... on how to deal with these issues ... I said [to the board] 'Let me talk about a ... hypothetical ... a girl who's 15 ... ' Anyway ... I talked to them and the Holy Spirit moved. They told me ... 'I'm really glad we have legal counsel and ... we really need to be reaching out and ministering.'

\section{Conclusions, Limitations, and Directions for Further Research}

This research has sought to examine a neglected topic in transgender studies and religious studies by deconstructing ex-gay discourses of "transgenderism" at all levels of society's gender structure. Revealing the mechanisms through which cisgenderism and transmisogyny operate, charting their means of discursive production and circulation, and examining their import and impact at all levels of social life helps us to better understand the oppression of transgender people, which is necessary to confront it. At the individual level, ex-gay discourses aim to shape how believers understand what transgenderism "is" and what it "does"; at the interactional level, they try to influence what Christians should "do" in their interactions with transgender people: Invalidate them. Ex-gay discourses provide not only the ideological and material fodder that fuels destructive attitudes and behavior toward transgender people, it animates the anti-transgender politics of the Christian Right that aggressively seeks to undermine the sanctity, autonomy, and legal existence of transgender people. This is especially concerning for minors, and others who have the least control over religious, medical, and legal decisions made on their behalf, often without their assent. The World Health Organization's recent decision to remove "gender dysphoria" from the ICD-11 is encouraging but does not allay concerns (Schwend et al. 2018; Mallory et al. 2018) about youth subjected to "change" attempts by counselors. In most countries (including a majority of the US), such "therapies" are not proscribed by law or professional mental health associations. Further, religious mental and medical health professional associations in the US are joining Christian Right litigation efforts to oppose legislation and regulation that would prohibit these practices by licensed health providers. As we have shown, they are increasingly engaging these efforts internationally.

This study documents how "transgenderism" has permeated ex-gay discourses from the 1970s through the present. Religion and psychology are powerful ideological weapons used to invalidate transgender people and result in significant, material consequences (including and beyond spiritual and psychological suffering). Research clearly shows that minority stress, rather than any moral or mental attribute, significantly diminishes the quality of life for transgender people. Further, when systems of power collude with religious and scientific cisgenderism to influence public policy and health care, it confers moral and medical authority to invade and abuse the most interior and exterior realities of our humanity.

There are several limitations of this study. First, although the ex-gay movement and Christian Right are transnational, we have focused narrowly on the movement's US-American and, to a lesser extent, European discourses. More in-depth research should investigate how these discourses manifest in 
policies and practices of other institutional settings, such as public and private schools (see Jones 2015), and in other regions of the world, as well as at the United Nations, where Christian Right organizations hold consultative status. Second, we suggest that this movement is gaining momentum despite the closure of EXODUS and the passage of some laws and regulations (in and beyond the US) banning attempts to change SOGIE by licensed professionals. Further research should empirically assess our appraisal and more deeply interrogate the strength and trajectory of this movement. This is a complicated endeavor for several reasons. The movement is transnational and shape shifting. As we have shown, today's movement works with a variety of allies to disseminate its message, continually revising what "change" means and what justifies it (in response to public scrutiny and legal challenges). Further, many of the organizations we examined have received scholarly attention in ex-gay research; there are others worthy of study. Examining those most known and/or politically active gives cover to organizations and individuals that sustain the gender structure generally and target transgender people specifically. The movement's trajectory is also subject to history, which is not linear. Transgender people in the US will feel the effects of Trump's policy decisions and judicial appointments far beyond the life of this administration. As Jones (2018) has shown, the executive decisions of the US president affect transgender students transnationally. Third, research should assess the harms perpetrated by the predominantly US-based ex-gay movement and its allies on people in other countries. We agree with Jones (2018) that this must include and go beyond how this movement (and the US government) has sanctioned anti-transgender policies and practices, particularly in the global South. There must also be justice, including a commitment, from a variety of stakeholders in the US, to long-term, collaborative (not controlling) partnerships in support of local efforts in other countries to further progress for transgender people, backed by substantial resources (monetary, legal, and other). Fourth, we did not have space here to flesh out themes that differentiate ex-transgender testimonials of men and women, or the ways in which movement discourses of transmasculinity and transfemininity differ. We have observed transmisogyny in these discourses, and in so doing, we do not suggest or imply that cisgenderism poses no unique harms to transgender men or transmasculinity. Further research should specifically interrogate these topics and illuminate how ex-gay discourses uniquely depict a range of groups of people included in (and excluded from) the umbrella term "transgender". Finally, we did not have space to include the voices of people who were once involved in this movement and have since renounced their views. We need to hear, and hold, these voices. They are necessary for understanding the movement's impact on our spirits, our psyches, and our humanity. No doubt, we have not identified all of the limitations of this work. We hope that scholars pursue, in greater depth and insight, some of the issues we raise here and related topics we have neglected. We think this kind of work, in the current political moment, is vital.

Author Contributions: Both authors designed the study, developed the theoretical frameworks, and wrote the manuscript. C.M.R. gathered and analyzed the data.

Funding: This research was funded solely by internal grants from James Madison University, including the JMU Program of Grants for Faculty and Educational Leaves and the Madison Caucus for Gender Equality.

Acknowledgments: We thank the anonymous reviewers for their valuable feedback on our manuscript. We also acknowledge and appreciate the diligent labors of student research assistants: Lauren Hughes, Emily Montgomery, Michael Smith, Shane Van Hoy, and Laurel Winsor.

Conflicts of Interest: The authors declare no conflict of interest.

\section{References}

Abbott, Douglas. 2009. Helping Children and Adolescents Develop Healthy Sexual Identities. Available online: http://familyfaithlife.weebly.com/uploads/1/3/9/1/13913896/understanding_same-sex_attraction.pdf (accessed on 10 June 2010).

Adams, Parker. 2005. Working with Parents of GID Boys. Paper presented at the NARTH Conference, Marina del Rey, CA, USA, November 11-13. Encino: National Association for Research and Therapy of Homosexuality. 
Alliance Defending Freedom and North Star Law and Policy Center. 2017. Available online: adflegal.blob.core.windows.net/mainsite-new/docs/default-source/documents/resources/media-resources/ letters/letter-to-minnesota-school-districts-(2017-08-03)/letter-to-minnesota-school-districts-(2017-08-03) .pdf?sfvrsn=2e6da2e4_4 (accessed on 18 February 2019).

Alliance Defending Freedom International. 2015. Legal Brief to the European Court of Human Rights. Available online: adf-ap-and-others-v-france-echr-brief.pdf (accessed on 2 October 2018).

American College of Pediatricians. 2016. Gender Dysphoria in Children. Available online: www.acpeds.org/thecollege-speaks/position-statements/gender-dysphoria-in-children (accessed on 14 July 2017).

American College of Pediatricians. 2018. Joint Letter to HHS, DOJ, DOE. Available online: https://www.acpeds.org/wordpress/wp-content/uploads/14.4.18-Final_Revised_-12.4.18-Joint-letterto-HHS-DOJ-DOE-Uphold-Definition-of-Sex.pdf (accessed on 14 July 2017).

American Psychological Association. 2008. Resolution on Transgender, Gender Identity and Gender Expression Non-Discrimination. Available online: www.apa.org/about/policy/transgender.aspx (accessed on 24 November 2017).

Ansara, Y. Gavriel. 2015. Challenging Cisgenderism in the Ageing and Aged Care Sector: Meeting the Needs of Older People of Trans and/or Non-Binary Experience. Australasian Journal on Ageing 34: 14-18. [CrossRef] [PubMed]

Ansara, Y. Gavriel, and Peter Hegarty. 2012. Cisgenderism in Psychology: Pathologizing and Misgendering Children from 1999-2008. Psychology and Sexuality 3: 137-60. [CrossRef]

Ansara, Y. Gavriel, and Peter Hegarty. 2013. Misgendering in English Language Contexts: Applying Non-cisgenderist Methods to Feminist Research. International Journal of Multiple Research Approaches 7: 160-77. [CrossRef]

Baltimore Sun. 2019. Transgender, LGBT Rights at Risk Again. Available online: https://www.baltimoresun.com/ news/opinions/editorial/bs-ed-0124-transgender-lgbt-court-attacks-20190123-story.html (accessed on 15 February 2019).

Barber, Matt. 2016. 'Transgender' Conditioning is 'Child Abuse'. Barbwire, March 20. Available online: www.barbwire.com/2016/03/20/transgender-conditioning-is-child-abuse/ (accessed on 3 September 2018).

BBC Radio. 2017. Parents Remove Son from School in Pupil Gender Row. BBC Radio, September 11. Available online: www.bbc.com/news/uk-england-hampshire-41224146 (accessed on 4 April 2018).

Beardsley, Christina, and Michelle O'Brien, eds. 2016. This Is My Body: Hearing the Theology of Transgender Christians. London: Darton, Longman, and Todd.

Berger, Joseph. 2013. Comments to the House of Commons Standing Committee on Justice and Human Rights Regarding Bill C-279. Available online: www.tfp.org/wp-content/uploads/2015/03/arpacanada.ca_ attachments_article_1724_Testimony\%of\%20Dr.\%20Berger\%20re\%20c279.pdf (accessed on 22 July 2015).

Berry, Susan. 2015. Doctors Slam American College of Physicians for Caving to the LGBT Agenda. Breitbart Newws, May 13. Available online: www.breitbart.com/big-government/2015/05/13/exclusive-doctors-slam-americancollege-of-physicians-for-caving-to-lgbt-agenda/ (accessed on 22 July 2015).

Bettcher, Talia Mae. 2013. Evil Deceivers and Make Believers: On Transphobic Violence and the Politics of Illusion. In The Transgender Studies Reader, 2nd ed. Edited by Susan Stryker and Aren Z. Aizura. New York: Routledge, pp. 278-90.

Blackwell, Danny. 2005. Outreach to the Wild Side. Paper presented at the EGA Conference, Toronto, ON, Canada, May 11-14. Ajax: Exodus Global Alliance.

Blackwell, Danny. 2008. Ministry to People with Transgender Issues. Paper presented at the EGA Conference, Toronto, ON, Canada, May 8-10.

Bochanski, Philip G. 2018. Authentic Pastoral Care in Light of Confusion about Sexual Identity. Paper presented at the Truth and Love Conference, Bloomfield, CT, USA, October 23.

Boone, Pat. 2012. Coming Out: True Stories of the Gay Exodus, Revised. Los Angeles: Boone Books.

Boyle, David. 2015. Brief of Amicae Curiae Dawn Stefanowicz and Denise Shick in Support of Respondents. Available online: www.supremecourt.gov/ObergefelHodges/AmicausBriefs/14-556_Dawn_Stefanowic_and_ Denise_Shick.pdf (accessed on 19 February 2017).

Brown, Michael. 2015. Our Culture Celebrates Transgender Transformations. Why Not Self-Amputations? Available online: www.stream.org/aren\T1\textquoterightt-celebrating-self-amputations (accessed on 29 September 2017). 
Brown, Michael. 2016. It's Time to Stand Up to Transgender Activism. April 21. Available online: https: //askdrbrown.org/library/it\%E2\%80\%99s-time-stand-transgender-activism (accessed on 29 September 2017).

Burack, Cynthia. 2008. Sin, Sex, and Democracy: Antigay Rhetoric and the Christian Right. New York: State University of New York Press.

Burroway, Jim. 2006. NARTH Exfoliates. Available online: www.boxturtlebulletin.com/2009/09/01/85 (accessed on 12 August 2010).

Butler, Judith. 2006. Undiagnosing Gender. In Transgender Rights. Edited by Paisley Currah, Richard M. Juiang and Shannon Price Minter. Minneapolis: University of Minnesota Press, pp. 274-98.

Byrd, A. Dean, and Stony Olsen. 2002. Homosexuality: Innate and Immutable? Regent University Law Review 14: 513-54.

Cacho, Lisa Marie. 2012. Social Death: Racialized Rightlessness and the Criminalization of the Unprotected. New York: New York University Press.

California Legislative Council. 2012. Bill Analysis of SB 1172. Available online: www.legalinfo.ca.gov/pub/11-12/ bill/sen/sb_1151-1200/sb_1172_cfa_20120529_161232_sen_floor.html (accessed on 14 July 2018).

Careless, Sue. 1997. Exodus: Escaping from the Gay Lifestyle. September 29. Available online: http: //www.theinterim.com/issues/society-culture/exodus-escaping-from-the-gay-lifestyle/ (accessed on 6 June 2017).

Carroll, Jerry. 1977. Changing a Sinful Life: Religious Wooing of Gays. The San Francisco Chronicle, May 13.

Clark, Julie, and Chris Jackson. 2018. Global Attitudes toward Transgender People. Ipsos. Available online: www.ipsos.com/en-us/news-polis/global-attitudes-toward-transgender-people (accessed on 20 December 2018).

Clinton, Tim, and George Ohlschlager. 2010. The Client's Right to Self-Determination. Paper presented at Liberty University Law Conference, Lynchburg, VA, USA, February 12.

Clinton, Tim, and Eric Scalise. 2016. The Case for Faith: Celebrating Hope in Mental Health Care. Available online: https://www.aacc.net/2016/11/03/the-case-for-faith (accessed on 19 July 2018).

Clucas, Rob. 2015. Religion. In The Palgrave Handbook of the Psychology of Sexuality and Gender. Edited by Christina Richards and Meg John Barker. New York: Palgrave-McMillan, pp. 447-63.

Clucas, Rob. 2017. Sexual Orientation Change Efforts, Conservative Christianity and Resistance to Sexual Justice. Social Sciences 6: 54. [CrossRef]

Comiskey, Andrew. 2014. Tran-Wreck. Available online: www.andrewcomiskey.com/tran-wreck (accessed on 6 June 2016).

Comiskey, Andrew. 2018. Reality, Healing. Available online: www.andrewcomiskey.com/reality-healing (accessed on 20 December 2018).

Congressional Record. 2016. Available online: https://www.congress.gov/congressional-record/2016/06/07/housesection/article/H3495-1 (accessed on 2 May 2018).

Conroy, Melissa. 2010. Treating Transgendered Children: Clinical Methods and Religious Mythology. Zygon: Journal of Religion \& Science 45: 301-16.

Cox, Shirley. 2009. Understanding the Different Types of Therapy Used to Treat Unwanted Same-Sex Attractions. Salt Lake: Foundation for Attraction Research. Available online: https:/family-faithlifeweebly.com/uploads/1/3/ 9/1/13913896/understanding_samesex_attraction.pdf (accessed on 3 July 2018).

Cragun, Ryan T., and J. E. Sumerau. 2017. No One Expects a Transgender Jew: Religious, Sexual and Gendered Intersections in the Evaluation of Religious and Nonreligious Others. Secularism and Nonreligion 6: 1-16. [CrossRef]

Cretella, Michelle. 2017. I'm a Pediatrician. How Transgender Ideology Has Infiltrated My Field and Produced Large-Scale Child Abuse. Available online: www.dailysignal.com/2017/07/03/im-pediatrician-transgenderideology-infiltrated-field-produced-large-scale-child-abuse/ (accessed on 10 May 2018).

Dacus, Brad. 2017. Available online: https://www.youtube.com/watch?v=2J1qu7O2Kjg\&list= PLMDsFGkhq65rOvgvVYsCeSL0T9xBn2b--\&index=50\&t=0s (accessed on 20 April 2018).

Dallas, Joe. 2008. The Transsexual Dilemma: A Dialogue about the Ethics of Sex Change. Available online: http://www.equip.org/article/the-transsexual-dilemma/ (accessed on 22 December 2017).

Dallas, Joe. 2016. Talking about Transgender: Why We Must; Where We Stand. May 27. Available online: www.joedallas.com/2016/05/27/talking-about-transgender-why-we-must-where-we-stand-parttwo-of-a-three-part-series (accessed on 22 December 2017). 
Dallas, Joe. 2017. Trans Actions. Available online: www.joedallas.com/2017/11/14/trans-actions/ (accessed on 22 December 2017).

Daly, Jim. 2012. Why This School Is OK with a Man Exposing Himself to Young Girls. November 13. Available online: www.jimdaly.focusonthefamily.com/why-this-school-is-o-k-with-a-man-exposinghimself-to-young-girls/ (accessed on 11 June 2017).

Davidson, Michael R. 2019. Letter from International Federation for Therapeutic Choice and Counseling to Maltese High Commissioner in London Ambassador Joseph Cole. February 11. Available online: https://d3uxejw946d7m5.cloudfront.net/wp-content/uploads/2019/02/IFTCC-LETTER-FOR-MALTAEMBASSY-11-Feb-2019-1.pdf (accessed on 11 February 2019).

Davidson, Michael R., Carys Moseley, and Christopher H. Rosik. 2018. A Response to the UK Government's Intended Ban on Therapeutic Choice. Available online: https://iftcc.org/es/novedades/iftcc-responds-to-theuk-governments-intended-ban-on-therapeutic-choice/ (accessed on 2 January 2019).

Desmond, Perry. 1978. Perry: A Transformed Transsexual. Ironton: Metamorphosis Books.

Diamond, Paul. 2016. State vs. Family: The Tyranny of the 'Emerging' Orthodoxy. December 9. Available online: https://www.thepublic-discourse.com/2016/12/18403 (accessed on 7 August 2017).

Diamond, Dan. 2018. The Religious Activists on the Rise inside Trump's Health Department. Available online: www.politico.com/story/2018/01/22/trump-religious-activists-hhs-351735 (accessed on 14 December 2018).

Dillworth, Marc. 2002. The Treatment of Childhood Gender Identity Disorder. Paper presented at the 2002 NARTH Conference, Orlando, FL, USA, November 9-10.

Dillworth, Marc. 2009. Prevention of Homosexuality: GID in Children. Paper presented at the Exodus Conference, Wheaton, IL, USA, July 14.

Dillworth, Marc. 2016. Understanding Homosexuality and Transgenderism. Paper presented at the Hope Rising Conference, Spartanburg, NC, USA, November 12.

Dobson, James. 2001. Bringing Up Boys. Carol Stream: Tyndale House.

Dobson, James. 2016. Protect Your Kids from Tyrant Obama. World Net Daily, May 30. Available online: www.wnd.com/2016/05/protect-your-kids-from-tyrant-obama/ (accessed on 16 July 2017).

Dueck, J. Alecia. 2012. Negotiating Sexual Identities: Lesbian, Gay, and Queer Perspectives on Being Mennonite. London: LIT Verlag.

Dueck-Read, Alicia. 2017. Breaking the Binary: Queering Mennonite Identity. Journal of Mennonite Studies 33: 115-33.

Duncan, KathyGrace. 2016. Walking in Truth. In Transgender Confusion: A Biblically Based QEA for Families. Edited by Denise Shick. Ashland: Help4Families Press, pp. 44-52.

Dworkin, Sari H., and Huso Yi. 2003. LGBT Identity, Violence, and Social Justice: The Psycho-logical is Political. International Journal for the Advancement of Counseling 25: 269-79. [CrossRef]

Dzmura, Noach, ed. 2010. Balancing on the Mechitza: Transgender in Jewish Community. Berkeley: North Atlantic Books.

Ensley, Mike. 2007. Uncovering Your Roots. Paper presented at the Exodus Conference, Irvine, CA, USA, June 26.

Evangelical Alliance and Parakaleo Ministry. 2006. Gender Recognition: A Guide for Churches to the Gender Recognition Act. London: Evangelical Alliance and Parakaleo Ministry.

Evangelical Alliance Policy Commission. 2000. Transsexuality: A Report by the Evangelical Alliance Policy Commission. London: Evangelical Alliance.

Exodus Global Alliance. 2018. Responding within the Church to Transgender Issues. Available online: www.exodusglobalalliance.org/responding-to-transgender-issues.php (accessed on 2 February 2019).

Exodus International North America. 1996. Exodus International Referral Ministry List. In The Journal of Human Sexuality. Edited by George A. Rekers. Carrolton: Lewis and Stanley, pp. 105-12.

Fairclough, Norman. 1992. Discourse and Social Change. Cambridge: Polity Press.

Fausto-Sterling, Anne. 2012. Sex/Gender: Biology in a Social World. New York: Routledge.

Fitzgibbons, Richard P. 2005. The Desire for a Sex Change. Available online: https://couragerc.org/wp-content/ uploads/2018/02/transsexual_article.pdf (accessed on 5 August 2018).

Fitzgibbons, Richard P. 2011. Rights of Conscience and Gender Identity Disorder. Appearance on Moody Radio. In Market with Janet Parshall. January 12. Chicago: Moody Bible Institute.

Fitzgibbons, Richard P. 2015. Gender Identity Disorder in Children: Will Jack Be Happier If We All Pretend He's Jill? Available online: www.aletia.org/en/health/article/gender-identity-disorder-in-children-will-jack-behappier-if-we-all-pretend-hes-jill-5806236423421952 (accessed on 5 August 2018). 
Fitzgibbons, Richard P. 2017a. Gender Identity Disorder. Available online: http:/www.maritalhealing.com/ conflicts/genderidentititydisorder.php (accessed on 5 August 2018).

Fitzgibbons, Richard P. 2017b. The Transgender Agenda vs. the Science. Available online: www.thecatholicthing. org/2017/06/28/the-transgender-agenda-vs-the-science (accessed on 5 August 2018).

Fitzgibbons, Richard, and Joseph Nicolosi. 2001. When Boys Won't Be Boys: Childhood Gender Identity Disorder. In Lay Witness Newsletter (June). Hopedale: Catholics United, pp. 21-26.

Fitzgibbons, Richard, Philip Sutton, and Dale O'Leary. 2009. The Psychopathology of 'Sex Reassignment' Surgery: Assessing its Medical, Psychological, and Ethical Appropriateness. National Catholic Bioethics Quarterly 9: 109-37. [CrossRef]

Focus on the Family. 2015. "Transgenderism" Brings Chaos from Order. Available online: https://www.focusonthefamily.com/socialissues/sexuality/transgenderism/transgenderism-bringschaos-from-order (accessed on 5 June 2015).

Forbes, Alexis. 2017. Criminalization of Transgender People. In The SAGE Encyclopedia of Psychology and Gender. Edited by Kevin Nadal. Thousand Oaks: SAGE, pp. 395-98.

Ford, Zach. 2013. Anti-LGBT Group Admits it Invented Story about Transgender Student Harassing Classmates. Available online: www.thinkprogress.org/anti-lgbt-group-admits-it-invented-story-about-transgenderstudent-harassing-classmates-updated-d66f40c01517/ (accessed on 3 January 2014).

Foster, David Kyle. 1996. Interview with a Former Transsexual and Transvestite. Mastering Life Newsletter 12 \& 13. Available online: $w w w . m a s t e r i n g l i f e . o r g / i n d e x . p h p ? v i e w=$ article\&catid=43\%3Atransgender-disorders\&id= 129\%3Ainterview-with-a-former-transsexual-and-transvestite\&option=com_content\&Itemid=29 (accessed on 10 February 2018).

Foster, David Kyle. 2017a. TranZformed: Finding Peace with Your God-Given Gender. Mount Juliet: Pure Passion Media and Mastering Life Ministries.

Foster, David Kyle. 2017b. The Truth about the Transgender Movement. Available online: www.facebook.com/notes/pure-passion/the-truth-about-the-transgender-movement-by-dr-davidkylefoster/1546927955338710 (accessed on 10 February 2018).

Gagnon, Robert. 2002. The Bible and Homosexual Practice: Texts and Hermeneutics. Nashville: Abingdon Press.

Gagnon, Robert. 2007. Transsexuality and Ordination. Available online: www.robgagnon.net/articles/ TranssexualityOrdination.pdf (accessed on 6 June 2016).

Gagnon, Robert. 2015b. Why Christians Should Not Throw Reparative Therapy under the Bus. Available online: www.josephnicolosi.com/collection/robert-a-j-gagnon (accessed on 6 June 2016).

Geiger, Tim. 2016. Transgenderism: The Reshaping of Reality. Available online: www.harvestusa.org/ transgenderism-reshaping-reality/\#.Wy49WNJKjIU (accessed on 22 July 2018).

Geiger, Tim. 2017. Fluid Family: Redemptive Responses When Family Members Identify as Transgender. Paper presented at the CCEF Conference, Frisco, TX, USA, October 13-15.

Gerber, Lynne. 2015. Grit, Guts, and Vanilla Beans: Godly Masculinity in the Ex-Gay Movement. Gender E Society 29: $26-50$.

Gogarty, Kayla. 2019. Extreme Anti-LGBTQ Groups Family Research Council and American College of Pediatricians Were on Capitol Hill Fighting the Equality Act. March 21. Available online: https://www.mediamatters.org/blog/2019/03/21/Extreme-anti-LGBTQ-groups-Family-ResearchCouncil-andAmerican-Collge-of-Pediatricians-we/223208 (accessed on 25 March 2019).

Goldberg, Arthur. 2007. Beyond Therapy: A Process of Gender Affirmation. Paper presented at the NARTH Conference, Irving, TX, USA, October 26-28.

Goldberg, Arthur. 2008. Light in the Closet: Torah, Homosexuality, and the Power to Change. New York: Red Heifer Press. Golub, Sarit, Ja'Nina Walker, Buffie Longmire-Avitral, David S. Bimbi, and Jeffrey T. Parsons. 2010. The Role of Religiosity, Social Support, and Stress-Related Growth in Protecting against HIV Risk among Transgender Women. Journal of Health Psychology 15: 1135-44. [CrossRef] [PubMed]

Greenberg, Julie. 2006. The Roads Less Traveled: The Problem with Binary Sex Categories. In Transgender Rights. Edited by Paisley Currah, Richard M. Juiang and Shannon Price Minter. Minneapolis: University of Minnesota Press, pp. 51-73.

Hale, Meaghen. 2012. APA Considers Eliminating Gender Identity Disorder, Replace with 'Gender Dysphoria'. Available online: https:/www.lifesitenews.com/news/apa-to-eliminate-gender-identity-disorder-replacewith-gender-dysphoria (accessed on 22 July 2013). 
Hall, Gae. 2013. He Can NEVER Be She. Newcastle: Expose Ministries.

Hall, Gae. 2015. Cross-Dressing: Does it Really Matter? In When Hope Seems Lost. Edited by Denise Shick. Ashland: Help4Families Press, pp. 140-49.

Harbin, Jessie. 2017. A Transgender Story: From David to Dee. AUTHENTIK Magazine, February 17. Available online: authentikmag.com/405-a-transgender-story-from-david-to-dee/ (accessed on 5 May 2018).

Harley, J. Grace. 2012. Former Transgender Testifies before Maryland House of Representatives. Annapolis and La Habra: The Road to Emmaus, September 15. Available online: http://www.theroadtoemmaus.org/RdLb/22SxSo/ PnSx/HarleyGTestifies.html (accessed on 2 November 2018).

Hartzell, Judith. 2015. By God's Design: Overcoming Same-Sex Attractions. Greenville: Ambassador International.

Haynes, Laura. 2017. Testimony Defending the Right to Therapy for Unwanted Same-Sex Attraction or Unwanted Gender Identity. Arlington: National Task Force for Therapy Equality. Available online: www.therapyequality.org/wp-content/uploads/2017/08/Dr-Laura-Haynes (accessed on 2 February 2019).

Haynes, Laura. 2018. Pathways to Heterosexual and Homosexual Development. Restored Hope Network Conference. Available online: www.restoredhopenetwork.org/hope-2018-conference-audio (accessed on 2 February 2019).

Heath, Geoff. 2018. Trending Topics. Paper presented at the Alliance for Therapeutic Choice and Scientific Integrity Training Institute, Orlando, FL, USA, October 5-6.

Help 4 Families. 2016. Position Paper on Transgender Marriage. Available online: www.help4families.com/ position-papers (accessed on 28 December 2016).

Herman, Jodi. 2013. Gendered Restrooms and Minority Stress: The Public Regulation of Gender and Its Impact on Transgender People's Lives. Available online: www.williams-institutelawucla.edu/wp-content/uploads/ Herman-Gendered-Restrooms-and-Minority-Stress-June-2013.pdf (accessed on 5 May 2016).

Heyer, Walt. 2013. Gender, Lies, and Suicide: A Whistleblower Speaks Out. Middletown: Make Waves Publishing.

Heyer, Walt. 2018a. Testimony. Paper presented at the International Conference on Gender, Sex, and Education, Madrid, Spain, February 23.

Heyer, Walt. 2018b. Amicus Brief to the US Supreme Court. Available online: www.supremecourt.gov/DocketPDF/ 18/18-658/77351/20181221134718537_Amicus\%20Curiae520Brief_12-21-18.pdf (accessed on 5 February 2019).

Hruz, Paul. 2018. Gender Dysphoria in Children. Paper presented at the CMDA Conference, Ridgecrest, NC, USA, April 26.

Hughto, Jaclyn M. White, Sari L. Reisner, and John E. Pachankis. 2015. Transgender Stigma and Health: A Critical Review of Stigma Determinants, Mechanisms, and Interventions. Social Science and Medicine 147: 222-31. [CrossRef] [PubMed]

James, Sandy E., Jody L. Herman, Susan Rankin, Mara Keisling, Lisa Mottet, and Ma'ayan Ana. 2016. The Report of the 2015 U.S. Transgender Survey. Washington, DC: National Center for Transgender Equality.

Johnson, John H., ed. 1976. Transsexual Reborn; Wants to Return as a Man. In Jet Magazine, November 4. Chicago: Johnson Publishing Company, p. 28.

Jones, Tiffany. 2015. Policy and Gay, Lesbian, Bisexual, Transgender and Intersex Students. New York: Springer.

Jones, Tiffany. 2018. Trump, Trans Students and Transnational Progress. Sex Education 18: 479-94. [CrossRef]

Kennedy, John W. 2008. The Transgender Moment. Christianity Today 52: 54-58.

Laqueur, Thomas. 1992. Making Sex: Body and Gender from the Greeks to Freud. Cambridge: Harvard University Press.

Laurence, Lianne. 2017. Psychologist Condemns Ontario Plan to Provide Sex-Reassignment Surgery as an 'Act of Inhumanity'. Available online: www.lifesitenews.com/news/act-of-inhumanity-psychologist-blasts-liberalson-sex-reassignement-surgery (accessed on 4 February 2018).

Leach, Jerry. 2001. Flight Toward Woman. Lexington: Reality Resources Publications.

Leggiere, Brian. 2004. Transvestic Fetishism: Alternate Life-Style or Narcissistic Disturbance? Paper presented at the NARTH Conference, Washington, DC, USA, November 12-14.

Lev, Arlene Istar. 2006. Disordering Gender Identity. Gender Identity Disorder in the DSM-IV-TR. Journal of Psychology \& Human Sexuality 17: 35-69.

Liberty Counsel. 2015. Parent Fights Transgender Education in Public School. Available online: www.lc. org/newsroom/details/parent-successfully-fights-transgender-education-in-public-school (accessed on 26 December 2018). 
Liberty Counsel. 2016. Liberty Counsel Presents Fairfax Transgender Case to VA Supreme Court. Available online: www.lc.org/newsroom/details/072816-liberty-counsel-presents-fairfax-transgender-caseto-va-supreme-court-1 (accessed on 26 December 2018).

Liberty Counsel. 2018. Liberty Counsel Cases. Available online: www.lcorg/cases (accessed on 26 December 2018). Lindevaldsen, Rena M. 2006. An Interdisciplinary Approach to Litigation Concerning Same-Sex Attractions and Gender Identity Disorders. Paper presented at the NARTH Conference, Orlando, FL, USA, November 10-12.

Lindevaldsen, Rena M. 2013. A State's Obligation to Fund Hormonal Therapy and Sex-reassignment Surgery for Prisoners Diagnosed with GID. Available online: https://wwdigitalcommons.liberty.edu/lusol_fac_pubs/57/ (accessed on 26 December 2018).

Lloyd, Jean C. 2015. The Girl in the Tuxedo: Two Variations on Sexual Orientation and Gender Identity. Available online: www.thepublicdiscourse.com/2015/02/14388 (accessed on 22 July 2017).

Long, Timothy. 2018. Reintegrative Therapy Training: Highlights. Paper presented at the IFTCC Conference, Budapest, Hungary, October 19-21.

Lopez, Bobby, Andrea Williams, and Lynda Rose. 2018. The Challenge to Freedom of Conscience, Freedom of Speech, and Wider Society. Paper presented at the New Normal Conference, London, UK, November 12.

Lorber, Judith. 1993. Believing is Seeing: Biology as Ideology. Gender E Society 7: 568-81.

Lorence, Jordan. 2016. Available online: http://adflegal.org/detailspages/blog-details/allianceedge/016/05/26/ transitioning-at-the-north-carolina-dmv (accessed on 16 May 2017).

Lowe, Mary Elise. 2017. From the Same Spirit: Receiving the Theological Gifts of Transgender Christians. Dialog: A Journal of Theology 56: 28-37. [CrossRef]

Mallory, Christy, Taylor N. T. Brown, and Kerith J. Conron. 2018. Conversion Therapy and LGBT Youth. Los Angeles: The Williams Institute. Available online: https://williamsinstitute.law.ucla.edu/wp-content/uploads/ Conversion-Therapy-LGBT-Youth-Jan-2018.pdf (accessed on 4 January 2019).

Mathers, Lain A. B. 2017. Expanding on the Experiences of Transgender Nonreligious People: An Exploratory Analysis. Secularism and Nonreligion 6: 1-10. [CrossRef]

Mathers, Lain A. B., J. E. Sumerau, and Ryan T. Cragun. 2018. The Limits of Homonormativity: Constructions of Bisexual and Transgender People in the Post-Gay Era. Sociological Perspectives 61: 934-52. [CrossRef]

Matheson, David. 2013. Becoming a Whole Man. Scotts Valley: CreateSpace Independent Publishing.

Matheson, David A., David Pruden, Jerry Leach, and Scott Davis. 2003. Aggressive Healing in Coordination with Therapy. Paper presented at the NARTH Conference, Salt Lake City, UT, USA, November 7-9.

McGann, P. J., and Peter Conrad. 2007. Medicalization of Deviance. In The Blackwell Encylopedia of Sociology. Edited by George Ritzer. Hoboken: Wiley-Blackwell, pp. 1110-14.

McGann, P.J., David J. Hutson, and Barbara Katz Rothman, eds. 2011. Sociology of Diagnosis. West Yorkshire: Emerald Group Publishing.

McHugh, Paul, Paul Hruz, and Lawrence S. Mayer. 2017. Amicus Brief to the Supreme Court in Gloucester County School Board v. Dierdre Grimm. Available online: https://www.scotusblog.com/wp-content/uploads/2017/01/ 16-273-amicus-petitioner-mchugh.pdf (accessed on 4 June 2018).

Meyer, Doug. 2015. Violence against Queer People: Race, Class, Gender, and the Persistence of Anti-LGBT Discrimination. New Brunswick: Rutgers University Press.

Moberly, Elizabeth R. 1983a. Homosexuality: A New Christian Ethic. Cambridge: Clarke \& Co.

Moberly, Elizabeth R. 1983b. Psychogenesis: The Early Development of Gender Identity. London: Routledge.

Moberly, Elizabeth R. 1986. Attachment and Separation: The Implications for Gender Identity and for the Structuralization of the Self: A Theoretical Model for Transsexualism and Homosexuality. Psychiatric Journal of the University of Ottawa 11: 205-9. [PubMed]

Mogul, Joey L., Andrea Ritchie, and Kay Whitlock. 2011. Queer (In)Justice: The Criminalization of LGBT People in the United States. Boston: Beacon Press.

Mohler, Albert R. 2005. In Defense of the Natural Family. Available online: www.albertmohler.com/2005/04/07/indefense-of-the-natural-family (accessed on 6 June 2014).

Mohler, Albert R. 2011. Reparative Therapy, Homosexuality, and the Gospel of Jesus Christ. Available online: www. albertmohler.com/2011/07/19/reparative-therapy-homosexuality-and-the-gospel-of-jesus-christ (accessed on 6 June 2014).

Mohler, Albert R. 2015. We Cannot be Silent: Speaking Truth to a Culture Redefining Sex, Marriage, and the Very Meaning of Right and Wrong. Nashville: Thomas Nelson Publishing Company. 
Mollenkott, Virginia Ramey. 2007. Omnigender: A Trans-Religious Approach. Cleveland: Pilgrim Press.

Moon, Dawne, and Theresa W. Tobin. 2018. Sunsets and Solidarity: Overcoming Sacramental Shame in Conservative Christian Churches to Force a Queer Vision of Love and Justice. Hypatia 33: 451-68. [CrossRef]

National Task Force for Therapy Equality. 2017. Report to the Federal Trade Commission. Available online: www.therapyequality.org/national-task-force-therapy-equality-complaint-ftc-report (accessed on 19 July 2018).

Navarro, Ruben. 2018. Marriage, Family, Gender Ideology and the LGBTI Agenda at the United Nations. Paper presented at the International Conference on Gender, Sex, and Education, Madrid, Spain, February 23.

Nicolosi, Joseph. 1991. Reparative Therapy of Male Homosexuality: A New Clinical Approach. Northvale: Jason Aronson.

Nicolosi, Joseph. 2009. The 'Dr. Phil Show' Explores the Issue of Transgender Children. Available online: https://www.josephnicolosi.com/the-dr-phil-show-explores (accessed on 27 August 2016).

Nicolosi, Joseph. 2015. Should Human Nature Function According to Its Design? Available online: www.josephnicolosi.com/collection/2015/5/28/should-nature-funtion-according-to-its-design (accessed on 27 August 2016).

Nolland, Lisa Severine, Carys Moseley, Carlos D. Flores, Robert Oscar Lopez, James D. Lopez, Daniel Moody, John Nolland, Peter Saunders, Rick Thomas, and Julia Gasper. 2018. The New Normal: The Transgender Agenda. England and Wales: Wilberforce Publications Limited.

Nussbaum, Martha. 2010. From Disgust to Humanity: Sexual Orientation and Constitutional Law. New York: Oxford University Press.

O'Hara, Mary Emily. 2017. This Law Firm is Linked to Anti-Transgender Bathroom Bills Across the Country. NBC News, April 8. Available online: ww.nbcnews.com/feature/nbc-out/law-firm-linked-anti-transgenderbathroom-bills-across-the-country-n741106 (accessed on 6 May 2018).

O'Leary, Dale, and Peter Sprigg. 2015. Understanding and Responding to the Transgender Movement. Washington, DC: Family Research Council. Available online: https://www.frc.org/transgender (accessed on 3 June 2016).

Ohlschlager, George W., and Peter T. Mosgofian. 2012. Law for the Christian Counselor. Eugene: Wipf and Stock Publishers.

Pacific Justice Institute. 2018. California Lawmakers: Faith Practices Can be Punished as Fraud. Available online: www.pacificjustice.org/press-releases/california-lawmakers-faith-practices-can-be-punished-asfraud (accessed on 2 January 2019).

Paulk, John. 1998. Not Afraid to Change: The Remarkable Story of How One Man Overcame Homosexuality. Mukilteo: WinePress Publishing.

Payne, Leanne. 1991. Restoring the Christian Soul. Wheaton: Baker Books.

Payne, Leanne. 1999. Crisis in Masculinity. Wheaton: Baker Books.

Phelan, James. 2015. Gender Identity Disorder: Understanding and Responding. In When Hope Seems Lost. Edited by Denise Shick. Ashland: Help4Families Press, pp. 75-91.

Phelan, James, and Christopher Doyle. 2014. Sexual Orientation Change Efforts: Faith-Based Challenges in the Midst of Cultural and Legal Shifts. Available online: www.nacsw.org/Convention/Phelan/ SexualOrientationFINAL.pdf (accessed on 17 May 2015).

Philpott, Kent. 1975. The Third Sex: Six Homosexuals Tell Their Stories. Plainfield: Logos International.

Pickering, Paul. 2016. Paula, now Paul: A Man after God's Own Heart. Available online: hopeforwholeness.org/ paula-now-paul-a-man-after-gods-own-heart/ (accessed on 8 May 2017).

Pickup, David. 2018. Reparative Therapy. Paper presented at Mass Resistance Texas Conference, Killeen, TX, USA, October 27.

Pomrening, Mary. 2010. Snatched from the Darkness. Wheaton: Pastoral Care Ministries.

Pruden, David C. 2009. Understanding and Helping Teenagers Who Experience Same-Sex Attraction. Salt Lake: Foundation for Attraction Research. Available online: http:/familyfaithlife.weebly.com/uploads/1/3/9/1/ 13913896/understanding_same-sex_attraction.pdf (accessed on 3 July 2018).

Reisman, Judith, and Mary E. McAlister. 2016. The Origins of the Transgender Phenomenon: The Challenge and Opportunity for Training Lawyers, Judges, and Policymakers in the Historicity of Alfred Kinsey's Pansexual Worldview. Available online: digitalcommons.liberty.edu/lusol_fac_pubs/74 (accessed on 26 December 2018).

Rekers, George A. 1986. Inadequate Sex Role Differentiation in Childhood: The Family and Gender Identity Disorders. Journal of Family and Culture 2: 8-37. 
Rekers, George A. 2009. Treatment of Gender Identity Confusion in Children. Paper presented at the NARTH Conference, West Palm Beach, FL, USA, November 20-22.

Risman, Barbara J. 2004. Gender as a Social Structure: Theory Wrestling with Activism. Gender E Society 18: 429-50.

Risman, Barbara J. 2018. Where the Millennials Will Take Us: A New Generation Wrestles with the Gender Structure. New York: Oxford University Press.

Roberts, Vaughan. 2016. Transgender: Christian Compassion, Convictions, and Wisdom for Today's Big Questions. Epsom: The Good Book Company.

Robertson, Annabelle. 2004. Transgender: Hope for Those Who Desire Healing. Camarilla: Crosswalk. Available online: www.crosswalk.com/1291492/ (accessed on 27 June 2016).

Robillard, Michel. 2008. Transvestism. Paper presented at the EGA Conference, Toronto, ON, Canada, May 8-10.

Robinson, Christine M., and Sue E. Spivey. 2007. The Politics of Masculinity and the Ex-Gay Movement. Gender $\mathcal{E}$ Society 21: 650-75.

Robinson, Christine M., and Sue E. Spivey. 2015. Putting Lesbians in Their Place: Deconstructing Ex-Gay Movement Discourses of Female Homosexuality in a Global Context. Social Sciences 4: 879-908. [CrossRef]

Rodgers, Forrest R. 2018. Hate against the LGBT Community. In Hate Crimes: Typology, Motivations, and Victims. Edited by Robin Maria Valeri and Kevin Borgeson. Durham: Carolina Academic Press.

Rogers, Sy. 2005. Testimony. Paper presented at the EGA Conference, Toronto, ON, Canada, May 11-14.

Rogers, Sy. 2009. What Works for Me: Realistic Expectations, Part I at the Exodus International Conference, Wheaton, IL, USA, July 14-18.

Rohrer, Megan M. 2009. Queerly Lutheran: Ministry Rooted in Tradition, Scripture, and the Confessions. San Francisco: Wilgefortis.

Rood, Brian A., Sari L. Risner, Francisco I. Surace, Jae A. Puckett, Meredith R. Maroney, and David Pantalone. 2016. Expecting Rejection: Understanding the Minority Stress Experiences of Transgender and Gender-Nonconforming Individuals. Transgender Health 1: 151-64. [CrossRef]

Rosik, Christopher H. 2001. Conversion Therapy Revisited: Parameters and Rationale for Ethical Care. Journal of Pastoral Care 55: 47-67. [CrossRef]

Sargent, Brad. 1992. A New Man. Memphis: Love in Action.

Scalia, Paul D. 2016. The Devil, You Say? The Catholic Thing, June 26. Available online: www.thecatholicthing.org/ 2016/06/26/the-devil-you-say-2/ (accessed on 8 November 2018).

Schwend, Amets Suess, Sam Winter, Zhan Chiam, Adam Smiley, and Mauro Cabral Grinspan. 2018. Depathologising Gender Diversity in Childhood in the Process of ICD Revision and Reform. Global Public Health 13: 1585-98. [CrossRef]

Seiler, Linda. 2016a. Homosexuality in the Context of Missio Dei: A Response to Today's Sexual Crisis. Pneum Africa Journal 2: 10-24.

Seiler, Linda. 2016b. Such Were Some of You. Milwaukie: Restored Hope Network. Available online: www. restoredhopenetwork.org/images/stories/Linda_Seiler_Testimony_2016.pdf (accessed on 12 June 2017).

Serano, Julia. 2007. Whipping Girl: A Transsexual Woman on Sexism and the Scapegoating of Femininity. Berkeley: Seal Press.

Serano, Julia M. 2010. The Case against Autogynephilia. International Journal of Transgenderism 12: 176-97. [CrossRef] Serano, Julia. 2016. Outspoken: A Decade of Transgender Activism and Trans Feminism. Oakland: Switch Hitter Press. Sharp, Matt. 2016. Protecting Your Church in Today's Culture. Paper presented at the Next Level Conference, Savannah, GA, USA, February 3.

Shick, Denise. 2011. How Sexual Identity Can Affect the Family. Paper presented at the Exodus Freedom Conference, Ridgecrest, NC, USA, June 8.

Shick, Denise. 2015. When Hope Seems Lost. Ashland: Help4Families Press.

Shick, Denise. 2016a. The Embracing of the Transgender Community while Ignoring Romans 2:4. 25 February 2016. Available online: www.charismanews.com/opinion/55409-the-embracing-the-transgender-communitywhile-ignoring-romans-2-4 (accessed on 6 July 2017).

Shick, Denise. 2016b. Why We Should have Seen the Transgender Craze Coming. The Federalist, November 28. Available online: thefederalist.com/2016/11/28/seen-transgender-craze-coming (accessed on 6 July 2017).

Shick, Denise. 2016c. Transgender Confusion: A Biblical Based QEA for Families. Ashland: Help4Families Press. 
Shorto, Russell. 2005. What's Their Real Problem with Gay Marriage? (It's the Gay Part)". New York Times Magazine, June 19, pp. 34, 36-37.

Showalter, Brandon. 2017. He Lived as a Transgender Woman for Over 20 Years Until He Heard God Speak to Him. The Christian Post. Available online: www.christianpost.com/news/he-lived-as-a-transgender-womanfor-over-20-years-until-he-heard-god-speak-to-him-194937/75 (accessed on 4 January 2018).

Smith, Gregory A. 2017. Views of Transgender Issues Divide along Religious Lines. Available online: www. pewresearch.org/fact-tank/2017/11/27/views-of-transgender-issues-divide-along-religious-lines. (accessed on 19 February 2018).

Spade, Dean. 2003. Resisting Medicine: Re/modeling Gender. Berkeley Women's Law Journal 18: 15-37.

Spivey, Sue E., and Christine M. Robinson. 2010. Genocidal Intentions: Social Death and the Ex-Gay Movement. Genocide Studies and Prevention 5: 68-88. [CrossRef]

SPLC. 2016. Boykin Singles Out Trans People at Liberty Counsel Conference. Available online: www.splcenter. org/hatewatch/2016/03/08/boykin-singles-out-trans-people-at-liberty-counsel-conference (accessed on 16 August 2017).

SPLC. 2019. Anti-LGBT. Available online: www.splcenter.org/fighting-hate/extremist-files/ideology/anti-lgbt (accessed on 3 March 2019).

Stanley, Erik. 2015. Lunch and Learn: Lawsuits, Sexual Orientation, and Gender Identity. Paper presented at the NACC Conference, Cincinnati, OH, USA, June 23.

Stanton, Glenn. 2018. Loving my LGBT Neighbor: Victims of Fake Science. Paper presented at the International Conference on Gender, Sex, and Education, Madrid, Spain, February 23.

Staver, Mathew D. 2007. When a Licensure Board Denies Christian Practice: Concerted Legal Action to Protect Faith-Based Counseling. Paper presented at the AACC Conference, Nashville, TN, USA, September 12-15.

Staver, Mathew D. 2008. Transsexualism and the Binary Divide: Determining Sex Using Objective Rather than Subjective Criteria. Liberty University Law Review 2: 459-519.

Staver, Mathew D. 2009. The Impending Legal Threats Arising from Reparative Therapy. Paper presented at the AACC Conference, Nashville, TN, USA, September 16-19.

Staver, Mathew D. 2016. Supreme Court Blocks Transgender Ruling. Orlando: Liberty Counsel. Available online: www.lc.org/newroom/details/o080316-supreme-court-blocks-trangendeer-bathroom-ruling (accessed on 22 July 2017).

Steinmetz, Katy. 2014. The Transgender Tipping Point: America's Next Civil Rights Frontier. Time, May 29. Available online: http://time.com/135480/transgender-tipping-point (accessed on 2 August 2016).

Stone, Amy L. 2018. Gender Panics about Transgender Children in Religious Right Discourse. Journal of LGBT Youth 15: 1-15. [CrossRef]

Stryker, Susan. 2008. Transgender History, Homonormativity, and Disciplinarity. Radical History Review 100: 145-57. [CrossRef]

Stryker, Susan. 2017. Transgender History: The Roots of Today's Revolution, 2nd ed. New York: Seal Press.

Sumerau, J. E., and Ryan T. Cragun. 2018. Christianity and the Limits of Minority Acceptance in America: God Loves (Almost) Everyone. Lanham: Lexington Books.

Sumerau, J. E., Ryan T. Cragun, and Lain A. B. Mathers. 2015. Contemporary Religion and the Cisgendering of Reality. Social Currents 3: 293. [CrossRef]

Sutton, Philip M. 2015. Professional Care for Unwanted Same-Sex Attraction: What Does the Research Say? The Linacre Quarterly 4: 351-63. [CrossRef] [PubMed]

Takata, Susan. 2018. My Voice, My Story. Available online: www.voiceofthevoiceless.info/my-story-susan-takata (accessed on 28 December 2018).

Tannehill, Brynn. 2018. Everything You Ever Wanted to Know about Trans* (But Were Afraid to Ask). London: Jessica Kingsley Publishers.

Tiller, Keith. 2005a. Understanding and Helping Transvestites and Transexuals. Paper presented at the EGA Conference, Toronto, ON, Canada, May 11-14.

Tiller, Keith. 2005b. Testimony. Paper presented at the Exodus Global Alliance Conference, Toronto, ON, Canada, May 11-14.

Tiller, Keith. 2015. Toward an Understanding of Transgender Behaviors. In When Hope Seems Lost. Edited by Denise Shick. Ashland: Help4Families Press, pp. 108-22. 
Van den Aardweg, Gerard. 1986. On Transsexualism and Transvestism. In On the Origins and Treatments of Homosexuality. New York: Praeger Publishers, pp. 151-56.

Van den Aardweg, Gerard. 2011. Gender Identity Disorder in Children. Available online: www.cultureoflife.org/ 2011/01/04/gender-identity-disorder-in-children-2/ (accessed on 14 August 2016).

Van den Aardweg, Gerard. 2015. Transgenderism: An Endless Quest for 'The Real Me'. Available online: www.mercatornet.com/articles/view/transgenderism-an-endless-quest-for-the-real-me/17029 (accessed on 14 August 2016).

Van Meter, Quentin. 2018. The Terrible Fraud of Transgender Medicine. Paper presented at the IFTCC Conference, Budapest, Hungary, October 19-21.

Vonholdt, Chrstl. 1996. Striving for Gender Identity: Homosexuality and Christian Counseling. A Workbook for the Church. Hesse: Reichenberg Fellowship.

Vonholdt, Chrstl. 2018. Transgender Case Studies. Paper presented at the 2018 International Federation for Therapeutic Choice and Counseling Conference, Budapest Hungary, October 19-21. Available online: https://www.core-issues.org/video/dr-chrisl-vonholdt (accessed on 28 December 2018).

Wayne, Randall. 2000. Cross-Dressing and Christianity: A REAL Man's Struggle. Available online: https: //www.firststone.org/articles/post/cross-dressing-and-christianity:-a-real-mans-struggle (accessed on 22 August 2016).

Welch, Donald, Anthony Duk, and Aaron Bitzer. 2013. Amicus Brief to the United States Court of Appeals for the Ninth Circuit. Available online: cdn.ca9.uscourts.gov/datastore/general/2013/02/20/13-15023_answering_ brief.pdf (accessed on 20 July 2016).

Wenman, John. 2017. My Hardened Heart Softened. Available online: www.pfox.org/help-4-families-newsletter (accessed on 6 May 2018).

Westbrook, Laurel, and Kristen Schilt. 2014. Doing Gender, Determining Gender: Transgender People, Gender Panics and the Maintenance of the Sex/Gender/Sexuality System. Gender E Society 28: 32-57.

White, Russ. 1987. If I Can Change, You Can, Former Transsexual Tells Gays. Available online: www.articles. orlando.sentinel.com/1987-08-01/news/0180420138_1_homosexuality-2-corinthians-rogers (accessed on 6 May 2018).

Whitehead, Briar. 1993. Craving for Love. Oxford: Monarch Books.

Whitehead, Neil. 2000. Is Transsexuality Biologically Determined? Available online: www.mygenes.co.nz/ transsexuality.html (accessed on 25 August 2016).

Whitehead, Neil, and Briar Whitehead. 2016. My Genes Made Me Do it! Lafayette: Huntington House Publishers.

Williams, Andrea. 2018. Transgender in the UK-A Personal Story. Paper presented at the International Federation for Therapeutic Choice and Counseling Conference, Budapest, Hungary, October 19-21. Available online: www.youtube.com/watch?v=9BAk4HtCFeY (accessed on 28 December 2018).

Winters, Kelly. 2009. Gender Madness in Psychiatry: Essays from the Struggle for Dignity. Dillon: GID Reform Advocates. Wong, Melvin. 2013. Raising Gender-Confident Kids: A Practical Guide. Singapore: Armour Publishing.

Worthen, Frank. 2010. Destiny Bridge. Winnipeg: Word Alive Press.

Wright, Jo-Joy, and Daniel Moody. 2016. 'I'm Transgender': How to Respond. Paper presented at the New Normal Conference, London, UK, November 12.

Wright, Jo-Joy, Daniel Moody, and Brian Hadley. 2016. Education: Sexuality and Gender Confusion in Primary Schools and How to Respond. Paper presented at the New Normal Conference, London, UK, November 12.

Young, Neil J. 2016. We Gather Together: The Religious Right and the Problem of Interfaith Politics. New York: Oxford University Press.

(C) 2019 by the authors. Licensee MDPI, Basel, Switzerland. This article is an open access article distributed under the terms and conditions of the Creative Commons Attribution (CC BY) license (http://creativecommons.org/licenses/by/4.0/). 